\title{
MOLINA AND JOHN DUNS SCOTUS
}

\author{
Jean-Pascal Anfray
}

The influence of John Duns Scotus (1265/6-1308) on late medieval and early modern philosophy and theology can hardly be overlooked. The Subtle Doctor's concepts and doctrines set the shape of much of the discussions of the time, on the nature and subject of metaphysics, on the freedom of the will, and on the principles of morality. More precisely, Scotus's definition of being qua being as that to which being is not repugnant (cui non repugnat esse), ${ }_{1}^{1}$ and as a possible being, left a twofold legacy to later philosophy: on the one hand, his conception of metaphysics as a transcendental science of the univocal concept of being, and on the other hand the centrality of the notion of freedom, whose first manifestation is the contingency of the world order. During the Renaissance and early modern period, those who would qualify as Scotists were so many that the Cistercian Juán Caramuel Lobkowitz could claim that Scoti schola numerosior est aliis simul sumptis (the school of Scotus counts more than all the other schools taken together). ${ }^{2}$ Not only was the institutional authority of Scotus uncontroversial but his thought also exercised a more diffused influence. Jesuit philosophy and theology was undoubtedly the main channel of diffusion for Scotus's thought in the early modern era, and this, despite the fact that the ratio studiorum of the order (1586-99) made the study of Thomas Aquinas's doctrine the basis of their theological teaching. ${ }^{3}$ Especially well known is the importance of the Scotist

\footnotetext{
1 See John Duns Scotus, Quodl. q. 3, n. 2, ed. L. Wadding (Lyon: 1639), XII, 67; trans. F. Alluntis and A. Wolter, God and Creatures: The Quodlibetal Questions (Princeton: 1975), 61. Honnefelder, Duns Scotus (Munich: 2005) clearly states the twofold motivation that underlies Scotus's thought. On Scotus's metaphysics, see L. Honnefelder, Scientia transcendens: Die formale Bestimmtheit der Seiendheit und Realität in der Metaphysik des Mittelalters und der Neuzeit (Duns Scotus, Suárez, Wolff, Kant, Peirce) (Hamburg: 1990).

2 Theologia intentionalis (Lyon: 1664), l.II, c. 3, disp. 10, n. 1264, 273. Quoted in J. Schmutz, "L'héritage des Subtils: Cartographie du scotisme du XVII e siècle," Les Etudes philosophiques (2002/1): 51-81, at 53 .

${ }^{3}$ For a historical justification of this claim, see J. Schmutz, "L'héritage des Subtils," 6 gff. On teaching in general among the Jesuits, see L. Giard (ed.), Les jésuites à la Renaissance: Système éducatif et production du savoir (Paris: 1995).
} 
concept of the subject of metaphysics as the univocal ens inquantum ens in Francisco Suárez's (1548-1617) Disputationes metaphysicae. ${ }^{4}$

Molina is no exception to this. He is admittedly one of "Scotus's intellectual descendants." ${ }^{5}$ However, the impact of Scotus on the latter is more limited in scope and more problematic than with some of his famous fellow Jesuits, like Suárez and Gabriel Vázquez (1549-1604). Indeed, Molina's intellectual production (at least in its extant state) ranges over fewer topics than that of the Doctor eximius. In particular, the nature of the object of metaphysics and the discussion of eternal truths and divine ideas do not figure among Molina's chief preoccupations. In contrast to this, and somewhat unsurprisingly in the context of post-Tridentine theology, the discussion of the nature of free will and its reconciliation with God's foreknowledge, providence, and predestination is where Scotus's influence on Molina proves most important. ${ }^{6}$ The controversies de auxiliis that arose in reaction to Molina's teachings on grace and predestination in the Concordia provide evidence of an (at least tactical) proximity between the Jesuits and the Franciscans against the Dominicans. ${ }^{7}$ There are thus historical affinities between official Scotists and Molinists. But in this chapter I will try to give a philosophical assessment of the relation between Scotus and Molina. Here, the notion of influence should be understood

\footnotetext{
4 See Honnefelder, Scientia transcendens. Scotus's account of broadly logical modality (possible logicum) constitutes the background of all 17th-century discussion about the divine foundation of modality and the source of eternal truths and about the nature of possible beings. See T. Hoffmann, Creatura intellecta: Die Ideen und Possibilien bei Duns Scotus mit Ausblick auf Franz von Mayronis, Poncius und Mastrius (BGPTM, NF) 60 (Munster: 2002); J. Coombs, "The Ontological Source of Logical Possibility in Catholic Second Scholasticism," in The Medieval Heritage in Early Modern Metaphysics and Modal Theory, 1400-1700, ed. R. Friedman and L. Nielsen (Dordrecht: 2003), 191-229; J. Schmutz, "La querelle des possibles. Recherches philosophiques et textuelles sur la métaphysique jésuite, 1540-1767" (Doctoral Diss., EPHE-ULB: 2003).

5 The phrase is borrowed from D.C. Langston, God's Willing Knowledge: The Influence of Scotus' Analysis of Omniscience (University Park: 1986), at 53. There are not so many studies explicitly devoted to the question of Molina's relation to Scotus. E. Dekker is an exception; see his two papers "The Reception of Scotus' Theory of Contingency in Molina and Suarez," in Via Scoti. Methodologica ad mentem Ioannis Duns Scoti, ed. L. Sileo (Rome: 1995), 445-54 and "Does Scotus Need Molina? On Divine Foreknowledge and Co-Causality," in John Duns Scotus, Renewal of Philosophy, ed. E.P. Bos (Atlanta: 1998), 101-11.

6 Some of Scotus's meta-ethical doctrines on the foundation of natural law do play a role in Molina's other master work, the De iustitia et iure, but for lack of space, we shall not treat it here. See I. Mandrella, Das Isaak-Opfer: historisch-systematische Untersuchung zu Rationalität und Wandelbarkeit des Naturrechts in der mittelalterlichen Lehre vom natürlichen Gesetz (BGPTM NF) 62 (Munster: 2002), on the problem of divine dispensation of natural law for which Isaac's sacrifice is the case study.

7 See J. Schmutz, "L'héritage des subtils," 68.
} 
so as to include the conceptual frameworks, the explicit theses, and the more general (and less easily discernible) philosophical outlooks which display either a positive or a negative impact of Scotus on Molina. ${ }^{8}$ In what follows, I will try to diagnose such an influence on two specific and closely related topics: the metaphysics of free will and the problem of divine foreknowledge. ${ }^{9}$ The first part of this study provides a sketch of Scotus's theory (sections 1 to 7 ). In the second part (sections 8 to 13), the results of the first are confronted to Molina's criticisms and to his own doctrines. Finally, I will end this conclusion by retrospectively showing how Scotus could be interpreted as reconciling God's foreknowledge and human freedom in a way consistent with Molinism (section 14).

The idea of free will is absolutely central in order to understand Scotus's thought. According to him, the will is essentially a rational power, which means that it is not determined to a single effect, but instead it is a power of self-determination. The phrase "rational power" is taken from Book IX of Aristotle's Metaphysics (1046b4-6), where they are opposed to irrational powers, whose characteristic feature is that they are determined to a single effect. For instance, given appropriate circumstances (dryness of the atmosphere, etc.), fire burns wood. On the other hand a rational power is such that, given the same set of circumstances it can either produce a given effect or not produce it. But Scotus deeply transforms Aristotle's idea. Indeed, according to him, the purely cognitive faculties of

\footnotetext{
8 The purely historical question of Molina's exact knowledge of Scotus is not addressed here. From the explicit quotations, it appears that Molina knew and read the Ordinatio, especially Book I, dist. 38-39. I will refer to the Vatican edition: Ioannes Duns Scotus, Opera omnia, studio et cura Commissionis Scotisticae ad fidem codicum edita (Vatican City: 1950-), referred to as Vat., followed by volume and page number. Whether Molina knew the Quodlibetal Questions and the commentaries on Aristotle, and in particular the Questions on Metaphysics, is more dubious. The Lectura was unknown until its rediscovery by C. Balic in the 1920s. For this reason, I will mostly refer to the Ordinatio.

9 By a metaphysic of freedom, I mean the study of the metaphysical conditions necessary to ascribe freedom to a voluntary agent, setting aside the psychological considerations that any agent must satisfy in order to be endowed with a will. Scotus's considerations on free will are not restricted to the purely metaphysical notion of a power of self-determination, but also involve a moral psychological and a specifically ethical perspective; see the texts in Part II of A. Wolter, Duns Scotus on the Will and Morality (1st ed. 1986; Washington: 1997). However Molina's own conceptions in moral psychology are too scattered and cursory to provide a sufficiently rich comparison point with Scotus.
} 
mind, including the intellect, are irrational in this sense, and are accordingly natural powers (potentiae naturales). ${ }^{10}$ The will is the only rational power; it is not subject to causal determinism, and is the only cause of its decisions. ${ }^{11}$ This involves a departure from the Aristotelian principle according to which every moving thing is moved by something else (omne quod movetur ab alio movetur). ${ }^{12}$ Within the Aristotelian scheme, only passive potencies (what would be called liabilities), which are unable to actualize by themselves a single effect, are undetermined: a given piece of bronze might be shaped as a statue or as a bowl. But according to Scotus, far from betraying an imperfection, the will's indetermination is the hallmark of its excellency, or what Scotus calls a "superabundant sufficiency."13 That such a rational power escapes causal determinism but introduces "fresh starts" in the causal order of the world is clearly stated by Scotus: "I say that it is able to do what it does with no conceivable predetermination to act, so that the initial determination, both in the order of nature and in the order of time, occurs in the very placing of its act" (Questions on Metaphysics, IX, q. 15, n. 66, ooo, Will and Morality, 148). Or more briefly: "there is no other cause [of the will's willing something rather than something else] to be found except that the will is will" (ibid., n. 29, Will and Morality, 140). Free will is incompatible with causal determinism.

The existence of such a power of self-determination, and thus of a will, is an intuitive truth, something anyone can experience. ${ }^{14}$ Hence creatures like human beings enjoy free will. But the idea that the will "could have

10 Questions on Metaphysics, IX, q. 15, n. 20-41 (Opera philosophica vol. III and IV) (New York: 1997), IV, 680-86. There is a clear and useful account of the issues discussed in this paragraph in M.B. Ingham and M. Dreyer, The Philosophical Vision of John Duns Scotus: An Introduction (Washington: 2004) and T. Hoffmann, "The Distinction between Nature and Will in Duns Scotus," Archives d'Histoire Doctrinale et Littéraire 66 (1999): 189-224.

11 There is disagreement in Scotus scholarship on the respective role of will and intellect in the formation of a volition. Some texts say that intellect and will function as partial co-causes of the volition (see Lectura II, d. 25, q. un., n. 73, Vat. XIX, 254), while other passages ascribe to the cognitive representation only the role of a causa sine qua non, leaving the will as the total cause of the volition (Rep. II, d. 25, n. 22, ed. L. Wadding [Lyon: 1639], VI, 888). Interpreters disagree over whether these textual differences express a change of opinion (toward a more radical voluntarism) or not, and if the answer to the first question is affirmative, whether the second position represents a later stage of Scotus's thought. For a recent, clear statement of the issue, see Ingham and Dreyer, The Philosophical Vision of John Duns Scotus, 162-72.

12 See Scotus's discussion in Questions on Metaphysics, IX, q. 14, OP IV, 626-73.

13 Questions on Metaphysics, IX, q. 15, n. 31, OP II, 611, Will and Morality, 140: "est et alia superabundantis sufficientiae, quae est ex illimitatione actualitatis, vel simpliciter vel quodammodo."

14 Questions on Metaphysics, IX, q. 15, n. 30, OP II, 610. 
acted otherwise" needs some clarification. Scotus distinguishes various senses under which one can be said to be able to will the opposite. First, one may be such that she can have contrary volitions related to the same object, like loving something, and later hating it. But the will can also will different objects: someone who wants to drink may also want to eat. The first is a power for contrary acts, the second is a freedom for different objects. Only the latter is essential for freedom, and is found both in God and in creatures, because the former supposes some form of mutability, which cannot be found in God. ${ }^{15}$ Scotus sets the same distinction in terms of the difference between not willing (non velle) and willing that not (nolle). Thus if I hate something, in some way I refuse it, which Scotus describes as an act of nolition (nolle). But if I freely want to $A$, all I need in order to be free, is to be able not to will $A$.

There is another crucial distinction concerning the power to act otherwise. It can signify either a manifest power to will different acts and/ or objects successively, or what Scotus calls a "not so evident power": the power not to will something at the very instant that one wills something, and vice versa. ${ }^{16}$ The first power is evident: if I swim at some time, I am able to swim even if I am in now in the middle of the desert, provided one indexes the object of the power (i.e. swimming) to a later time than now. But in order to be free to swim, I should have the power to swim now, which I clearly lack. ${ }^{17}$ Similarly, for my will to be free, I must have the power now to refrain from willing what I will. This is a clear consequence of Scotus's claim that free will is incompatible with natural necessity. ${ }^{18}$ Natural powers are such that given if their causal requisites are present, there is no power at time $T$ for the opposite effect. By contrast, the will as a rational power has simultaneously the power to will the opposite or not to will anything at all. However, Scotus does not defend his position via this line of argumentation but instead uses the thought experiment of an angel existing for a single instant of time. This thought experiment allows

\footnotetext{
15 Ord. I, d. 38, p. 2-d.39, q. 1-5 (= I, d.39), n. 15, Vat. VI, 417; n. 21, Vat. VI, 425-26.

16 Ord. I, d. 39, n. 16, Vat VI, 417-18; Questions on Metaphysics, IX, q. 15, n. 65, OP IV, Will and Morality, 148.

17 The double time indexing of powers to $\varphi$ is essential to see how D. Langston is misled when he thinks that powers for Scotus are just abilities, not necessarily including opportunities. Having the power at $T$ to $\varphi$ at some time or another is enough for a mere ability. But when Scotus claims that freedom of action and/or will requires the power at $T$ to $\varphi$ at $T$, this entails that one has the power to $\varphi$ given the circumstances, which requires that one has the opportunity to exercise the power.

18 Ord. I, d. 1, p. 2, q. 2, n. 80, Vat. II, 60 : "Necessitas naturalis non stat cum libertate."
} 
Scotus to disprove any theory that grounds the contingency of an act at $T$ on what happens at any earlier time. Suppose an angel elicits a sinful act. Since sinning requires freedom of the will, this entails that at this very instant, the angel must be able to avoid sinning at this very moment.

The idea of a simultaneous power to will otherwise is only one aspect of a new modal framework which marks a clear departure from older modal paradigms, as Scotus scholars have largely insisted upon. The central feature of Scotus's new model is the theory of synchronic contingency. He developed his thought largely in reaction to a form of determinism held by those whom he names the "Philosophers," who promoted a broadly Aristotelian account of modality. ${ }^{19}$ A common feature of these thinkers was their adherence to a version of the Principle of Plenitude (i.e. no genuine possibility remains unactualized), which entails that whatever is eternal and/or immutable is (absolutely) necessary. One line of argument which could lead to this was their strict notion that actualization of any potentiality implies a process of change. The theory entails the necessity of the present, expressed by the Aristotelian dictum omne quod est, necesse est esse quando est (everything necessarily is, when it is, De interpretatione 19a23-27) which is then understood, not as an innocuous conditional necessity, but as a necessitas consequentis: "If $A$ occurs at $T$, then it is necessary (from $T$ on) that $A$ occurs at $T$."

Since any genuine possible state of affairs requires that some actual potency be able to bring it about, it follows that if some potency is immutable, then whatever results from it, necessarily does so. Therefore, if God is eternal and immutable, then whatever he produces is necessary. As a consequence, contingency is the result of the impedibility of causal chains relating the finite beings, which comes from the essential imperfection of secondary causes.

19 Ord. I, d. 8, p. 2, q. un, n. 251-55, Vat. IV, 294-97. On Scotus's new theory of synchronic contingency and its impact on the whole modal theory, see S. Knuuttila, "Time and Modality in Scholasticism," in Reforging the Great Chain of Being, ed. S. Knuuttila and J. Hintikka (Dordrecht: 1981), 163-257; Knuuttila, Modalities in Medieval Philosophy (London: 1993); A. Vos et al., John Duns Scotus: Contingency and Freedom. Lectura I 39 (Dordrecht: 1994); S. Dumont, "The Origin of Scotus's Theory of Synchronic Contingency," The Modern Schoolman 72 (1995): 149-67; C. Normore, "Duns Scotus's Modal Theory," in The Cambridge Companion to Scotus, ed. Th. Williams (Cambridge, Eng.: 2003), 129-6o. 
According to Scotus, the latter position is incoherent, for either there is contingency within finites things, and so their first cause has to be contingent, or God's productive action is necessary, and so are its effects. ${ }^{20}$ The background principle of Scotus's first argument is that necessity is a hereditary property: if $E$ is a necessary effect and $E$ is a cause of $E^{\prime}$, then $E^{\prime}$ is necessary too. ${ }^{21}$ The contingency of God's causation (which proves according to Scotus that he has will) is a necessary condition of the existence of contingent effects within the world. Scotus adds two arguments to this one. The first is based on the superiority of the first cause with respect to any caused event, and the other on the principle that the first cause is able to produce alone any effect produced by secondary causes. ${ }^{22}$ Any state of affairs that is contingent with respect to secondary causes does not cease to be so if it is directly brought about by the first cause.

Since the contingency of our world is a matter of fact, and this cannot consistently be denied, it follows that determinism is false. ${ }^{23}$ Moreover, since God acts through his will, and every will is essentially free, it follows that every created effect is contingent and there is no absolute, but only relative necessity in the realm of existing things other than God himself. ${ }^{24}$ Contingency is therefore absolutely universal on the one hand and, on the other, it has its root within God's will: "the divine will is the first ground (prima ratio) of contingency” (Rep. I A, d. 39-40, q. 1-3, n. 35, ed. Söder, 248). This does not preclude that there might be other sources of contingency, namely the created wills. ${ }^{25}$

20 Ord. I, d. 2, q. 1-2, n. 80-81.

21 Ord. I, d. 39, n. 12, Vat. VI, 412: "causa movens... si necessario movetur necessario movet."

22 Ord. I, d. 39, n. 12, Vat. VI, 413: "causa prior prius naturaliter respicit effectum suum quam causa posterior"; ibid.: "quidquid producitur a causis posterioribus, posset immediate produci a prima." Cf. Ord. I, d. 8, n. 287, Vat. IV, 315 .

23 In a famous example, he claims that whoever denies it should be tortured, until he acknowledges that it is possible for him not to be tortured. See Reportatio IA, d. 39-40, n. 30, ed. in J. Söder, Kontingenz, Wissen (BGPTM, NF) 49 (Munster: 1999), 247.

24 Ord. I, d. 39, n. 22, Vat. VI, 427: "ad quodlibet ergo aliud [ab essentia sua] contingenter se habet, ita quod posset esse oppositi." For the relative necessity and absolute contingency of natural events, see Rep. I A, d. 39-40, q. 1-3, n. 38, Söder, 249.

25 Scotus's argumentation at $\mathrm{Ord}$. I, d. 39, n. 14, Vat. VI, 416 relies on the possibility of understanding the divine will as a source of contingency on the basis of an understanding of our own created will. This presupposes that the latter are also (limited) sources of contingency. Scotus is even more explicit in Rep. I A, d. 39-40, q. 1-3, n. 36, ed. Söder, 249: "actus voluntatis meae habet duplicem causam contingentiae, unam ex parte voluntatis divinae sicut causae primae et aliam ex voluntate mea ut ex secunda causa." 
But this contingency can be reconciled with God's immutability only if one abandons the model of modality that goes along with the cosmology criticized by Scotus. In particular, he gives up the necessity of the Present. ${ }^{26}$ This is clearly expressed in the following definition of contingency: "I do not call contingent any non-necessary or non-permanent state of affairs, but a state of affairs whose opposite could occur while it occurs" (Ord. I, d. 2, p. 1, q. 1-2 n. 86, Vat. II, 179). The theory of synchronic contingency cannot be separated from the redefinition of possibility in terms of logical possibility (potentia logica). Some state of affairs is possible in this sense if and only if its constitutive elements are nonrepugnant. However, this is never mere logical possibility, since every logical power is actually matched by a real power. And Scotus claims that the will as a real power accompanies the logical possibility of the contrary act. ${ }^{27}$ The relation of repugnance is not as strict as logical contradiction, but is closer to semantic incompatibility. For instance, the predicates "red all over" and "green all over" express repugnant properties, though their combination would not violate any law of logic. ${ }^{28}$

By defining the will's real power on the basis of the logical possibility of the two preceding states of affairs, it might be thought that Scotus dramatically weakens the "could have willed otherwise" condition for free will, in a way that Once again, my swimming now is in itself nonrepugnant, and thus constitutes a possible state of affairs. All this can be interpreted as a matter of whether one considers more or less fine-grained states of affairs. If the time index of the action envisaged and the causal requisites are specified, then there is indeed some repugnance. For instance, the state of affairs expressed by the sentence "I am at $T$ at a place where none of the conditions required to swim are present and I swim at $T$ " would be repugnant, and this entails that it is impossible that I swim on this occasion and that I am not free to do it. ${ }^{29}$

26 Restricting the latter to mere conditional necessity, reinterpreting the Aristotelian principle in the following way: "Necessarily (if $A$ occurs at $T$, then $A$ occurs at $T$ )."

27 Ord. I, d. 39, n. 16, Vat. VI, 418: "hanc etiam potentiam realem activam... concomitatur potentia logica, quae est non-repugnantia terminorum. Voluntati enim ut actus primus, non repugnat oppositum velle." See Questions on Metaphysics, IX, q. 1-2, n. 18, OP IV, 514 .

28 Lectura I, d. 2, p. 2, q. 1-4, n. 246.

29 And so scotus claims that a real power is matched by a logical possibility; not to be read the other way round as if the mere per se nonrepugnancy of a state of affairs entailed that the agent has a real power. To get a real power, one needs to add an extrinsic with facts (already existing states of affairs) to the intrinsic 
The theory of synchronic contingency must face the charge of violating the law of contradiction. If we suppose that $p$ is true at $t$ and that it is possible at $t$ that $p$ is false at $t$, then, by supposing the possible actualization of not- $p$, that would entail that it is possibly true that $p$ is true at $t$ and $p$ is false at $t$ which is contradictory. In order to avoid such a contradiction, Scotus uses the distinction between the composed and the divides sense. The sentence "it is possible that $S$, not willing $A$ at $T$, wills $A$ at $T$ " is true in sensu divisionis but false in sensu composito. The latter amounts to the contradiction: "it is possible that ( $S$ wills $A$ at $T$ and that $S$ does not will $A$ at $T$ )." But in the sense of division, it means that " $S$ does not will $A$ at $T$ and it is possible at $T$ that $S$ wills $A$ at $T$ " which is not contradictory, provided one gives up belief in the necessity of the present, and true, since " $S$ wills that $A$ at $T$ " is nonrepugnant. ${ }^{30}$ But Scotus goes further and distinguishes an order within the momentary existence of the angel during which he commits a sin. Being free, the sinning angel is able to refrain from sinning at $T$. However, his act occurs and thus becomes a matter of fact. From the point of view of the agent, the volition is contingent, because he has both the power to sin and the power not to $\sin .{ }^{31}$ From the point of view of the volition, it either occurs or not. These two aspects are ordered according to an order of conceptual priority (natura prius) within a single instant. The will, insofar as it is considered as a power for opposites, is naturally prior to its exercising this power one way or the other (Vat. VI, 418). The true proposition corresponding to the divided sense of the sentence thus refers to two distinct instants of nature. As C. Normore summarizes: "the prior is that in which the angel has both the power to love God and the power to hate God, and the posterior is that in which the angel has actualized the power to love God." 32 In a similar way, though God's will is absolutely immutable, he wills contingently his objects, so that while he decides to create $A$ he could at the same time decide to create something else. ${ }^{33}$

nonrepugnancy. Scotus sometimes calls the corresponding kind of necessity necessitas inevitabilitatis. See Rep. I A, d. 39-40, q. 1-3, n. 27, ed. Söder, 246.

30 See Ord. I, d. 39, n. 17, Vat. VI, 419-20.

31 Rational powers are thus endowed with powers for effect. The angel does not have the contradictory power of sinning and not sinning at the same time, but two powers.

32 C. Normore "Duns Scotus's Modal Theory," 135. See also J. Schmutz, "Du péché de l'ange à la liberté d'indifférence: Les sources angélologiques de l'anthropologie moderne," Les Etudes Philosophiques (2002): 169-98 for uses of the same thought experiment during the early modern period.

33 Ord. I, d. 39, n. 22, Vat. VI, 427. 
Abandoning the necessity of the present has important consequences concerning the relationship between time and modality. Though the present is ontologically determinate, it is nevertheless contingent, so that logical determination does not entail necessity. ${ }^{34}$ This undercuts the fatalist inference in De interpretatione, Chapter 9, which derives the necessity of future states of affairs from the present truth of the propositions corresponding Nevertheless, Scotus does not completely separate time and modality. This appears in his reply to the objection that what is past is necessary and unavoidable, so that God's predestination entails that someone who is predestined is unable to sin. Scotus answers by first conceding the necessity of past states of affairs. ${ }^{35}$ The underlying intuition is the commonsense assumption that there are no backward-looking powers. However, since God exists in an eternal present, none of his acts passes away. Therefore, God's acts are eternally contingent, so that God can bring it about that if someone sins now it will never have been true that he was predestined. But this opens up a possible discrepancy between God's present and ours, or in other words between what is possible for God, and what is possible for us. ${ }^{36}$ If I was in Rome yesterday, there is nothing I can do now to prevent this from having happened. In contrast, God's eternal present coexists with our past, so that from God's perspective what is possible never becomes impossible. This, in turn, entails a tension over the nature of pastness.

\section{IV}

Thus far, we have examined the nature of free will and of contingency, its root in both divine and created will, and how it fits within the modal

34 Ord. I, d. 39, n. 26, Vat. VI, 432.

35 Lectura I, d. 40, q. un., n. 9, Vat. XVII, 512-13: “Ad primum argumentum quando arguitur quod illud quod transiit in praeteritum est necessarium — concedatur. Et quando arguitur quod 'istum praedestinari' transiit in praeteritum, dicendum quod hoc falsum est: si enim voluntas nostra semper haberet eandem volitionem in eodem instanti immobili, non esset sua volitio praeterita sed semper in actu. Et sic est de volitione divina, quae semper eadem est: unde sicut dictum est, eadem volitione qua vult aliquem praedestinare, potest velle eundem damnari pro eodem instanti aeternitatis. Unde quod dicitur in praeterito, quod Deus praedestinavit, ibi, 'praedestinavit' copulat nunc aeternitatis ut coexistit 'nunc' praeterito."

36 See C. Normore, "Duns Scotus's Modal Theory." 
framework. Now, we are in a position to turn to Scotus's account of God's knowledge. There is a preliminary problem concerning the scope of Scotus's inquiry. Traditionally, it is thought that Scotus answers two questions: (1) How does God know future contingents? And (2) is God's knowledge of future events compatible with their contingency? Following E. Dekker, we may call the first the Source question, and the second the Reconciliation question. ${ }^{37}$ Some recent interpreters deny that Scotus answers the Source question, and claim that he tried only to solve the Reconciliation question. There is some textual support for this view, ${ }^{38}$ and it has important consequences on the interpretation of Scotus's position as we will see. However, it is difficult not to read some passages as (perhaps incomplete) explanations of how God can be said to have knowledge of what is contingent. ${ }^{39}$ And, as will appear later, Molina understood Scotus as providing an account of the Source question. This is why I present Scotus's account along the traditional interpretation.

Scotus develops his own account of foreknowledge as an alternative to Aquinas's. The latter tried to explain the compatibility between the certitude of divine foreknowledge and the contingency of its objects by claiming that, though future events, in relation to the "now of time" (nunc temporis), are not yet actual and thereby contingent, they are nevertheless present to the now of eternity (nunc aeternitatis), and from this point of view their occurrence is determinate and necessary and can be the object of a certain knowledge. ${ }^{40}$ The idea of temporal things coexisting within God's eternity is the core of the theory. Eternity is agreed to be some kind of nonsuccessive duration. ${ }^{41}$ What is contentious is the notion of eternal presence. According to Scotus's realist interpretation, God, being eternal, is present to all the moments of time, and hence, to all events, past, present, and future. ${ }^{42}$ This presence implies a form of simultaneity. Therefore

37 See E. Dekker, "Does Scotus Need Molina?"

38 See especially the following passages: Lectura I, d. 39, n. 62, Vat. XVII, 500; Ord. I, d. 39, n. 22, Vat. VI, 427: "restat videre secundum principale, qualiter cum hoc stat certitudo scientiae" (cf. n. 12, Vat. VI, 413).

39 See Rep. I A, d. 38, q. 1-2, n. 11, ed. Söder, 227 and n. 37, 233: "sed quomodo hoc sit [i.e. quod Deus determinate novit alteram partem contradictionis cuiuslibet] respondeo."

40 Thomas Aquinas, Summa contra Gentiles, I, c. 66-67 and Summa Theologiae I, q. 14, a. 13 , in corp.

41 Traditionally, Boethius's definition of eternity is "aeternitas est interminabilis vitae tota simul et perfecta possessio" (Consolatio philosophiae, ed. L. Bieler [Corpus Christianorum Series Latina] 94/1 [Turnhout: 1957], V, pr. 6, l.9-11). See Thomas Aquinas, SCG I, c. 66 , n. 7 ; $S T$ I, q. 10, a. 4, in corp.

42 Lectura I, d. 39, n. 23, Vat. XVII, 486. 
things are present in themselves (in seipsis) to God, which entails that all moments of time somehow exist tenselessly in the now of eternity, as the points on the circumference of a circle are equidistant to its center, which can be represented as God's eternal now.

Scotus's objections are based on a dynamical conception of time, according to which the fluxus temporis is an objective feature of existence. ${ }^{43}$ Suppose one starts with the assumption that God coexists with some event $E$. This means that God is somehow simultaneous with $E$ occurring at $T$. Now, if God is present to another event $E^{\prime}$, occurring at $T$ ' future relative to $T$, then God is simultaneous with $E^{\prime}$, and, by the transitivity of simultaneity, $E$ and $E^{\prime}$ would be simultaneous too, which destroys their temporal order. Furthermore, $E$ ' would be real at $T$, and then it would be impossible for God to create it at $T^{\prime}$. And one could not reply that $E$ is not yet real, though simultaneous with God's eternity, for simultaneity being a real relation requires that its terms really exist. ${ }^{44}$ Pace the parallel with the case of immensity, Scotus considers that God's immensity entails that he is present to all existing places, not to possible but nonactual places. Likewise, God's eternity does not entail that nonactual times, like the future, are present to him, only that they will be, when they will be actualized. ${ }^{45}$ Another objection is that if God knew contingent events only because he perceives them somehow when they are present, then his knowledge would be imperfect, and could not ground his providence. ${ }^{46}$ Finally, if mere coexistence were sufficient to ground foreknowledge of the future contingent states of affairs, the angels would naturally foreknow them, which is denied by Aquinas himself. ${ }^{47}$

We may now turn to Scotus's positive account. According to him, God's knowledge contains three moments, or instants of nature. The first stage is God's natural knowledge of all necessary propositions. At this stage, every logical possibility is an object of God's knowledge, which depends only on

43 See Rep. IA, d. 38, n. 28, ed. Söder, 231: "tempus sic fluat quod non habet existentiam post fluxum. Si nihil remaneret nisi punctus, ergo nihil circumferentiae coexistit centro nisi punctus."

44 Ord. I, d. 39, n. 9, Vat. VI, 409.

45 Is the present the only real time, as the circle metaphor suggests (cf. Lectura I, d. 39, n. 85, Vat. XVII, 507; Ord. I, d. 39, n. 35, Vat. VI, 441), or does Scotus grant reality to the past as well? His remarks on the determination and necessity of the past (cf. Ord. I, d. 39, n. 26, Vat. VI, 432) tend to show that past events and states of affairs are somehow real. See N. Lewis, "Space and Time," in The Cambridge Companion to Scotus, ed. Th. Williams, 84-85.

46 Ord. I, d. 39, n. 10, Vat. VI, 411; Rep. IA, d. 38, q. 1-2, n. 24, ed. Söder, 230.

47 Ord. I, d. 39, n. 10, Vat. VI, 411; cf. Thomas Aquinas, ST I, q. 57, a. 3, in corp. 
his intellect. The process is slightly complicated. Consider the terms of the relations of repugnance and compossibility. These are logically simples and are sometimes called by Scotus notae. Such notae are related to others according to repugnance or compossibility, independently of any power to bring them about. ${ }^{48}$ However, they are not self-subsistent entities, but are the products of God's intellectual activity, which thus endows them with an ontological status, as intelligible beings. But the logical and modal properties of these entities are not constituted by God's intellectual activity. Scotus summarizes this by claiming that the possibilia are formally such from themselves (formaliter ex se), but "principially" from God (principiative ab eo $).{ }^{49}$ All logical, mathematical, and metaphysical truths, in general all necessary truths, are known at precisely the instant when God produces, thinks things, and produces them in an esse intelligibile. Moreover, since the relations of compossibility and repugnance are independent from God's intellectual activity, any modal truth is necessarily so. This entails that anything possible is necessarily possible. According to Scotus, all combinations of compatible notae are objects of God's knowledge, which he calls also ideas. ${ }^{50}$ Scotus is less explicit on the content of ideas than on their ontological status, but it is likely that an idea is an intellectual representation of any object, either of an individual like "Socrates" or of a common nature like "man" and that it contains everything that can be grasped by God through his intellect alone. An idea would be something like the deductive closure of all necessary truths concerning a given object. For instance, God's intellect produces the notae of animality and rationality and these, being intrinsically nonrepugnant, can be combined in a single subject, man. And man can be combined with an individual differentia to produce a possible individual, say "Socrates." The idea of Socrates contains all the properties grounding necessary truths concerning him: that he is a man, that he is a rational animal, and that it

48 Ord. I, d. 36, q. un., n. 6o-61, Vat. VI, 296. On what follows, see C. Normore, "Scotus, Modalities, Instants of Nature and the Contingency of the Present," in John Duns Scotus. Metaphysics and Ethics, ed. L. Honnefelder, R. Wood, and M. Dreyer (STGM) 53 (Cologne: 1996), 161-74.

49 See Ord. I, d. 43, n. 18, Vat. VI, 369.

50 Ord. I, d. 35, n. 42, Vat. VI, 263: "ipsum obiectum cognitum est idea." Scotus borrows the traditional Platonic terminology, but gives it a very different meaning. Against Henry of Ghent, he claims that ideas are not ontologically independent entities, enjoying an esse essentiae (Ord. I, d. 36, n. 34, Vat. VI, 284). And against Aquinas, Scotus claims that ideas are not exemplar forms, guiding God's practical knowledge of his creation. See Rep. I A, d. 36, q. 3, passim in T. Noone, "Scotus on Divine Ideas: Rep. Paris. I-A, d.36," Medioevo 24 (1998): 359-453. 
is possible that he is sitting at $T$, and so on. However, it does not include the property of sitting at $T$, because it is a contingent truth.

This leads Scotus to reject theories that ground God's knowledge of future contingents on his ideas. ${ }^{51}$ First, they can ground only analytical, thus necessary truths. ${ }^{52}$ Moreover, ideas are intellectual representations, excluding any volitional element. They are therefore purely natural occurrences in God's mind. Since God's will is the only root of contingency, it follows that ideas necessarily have their content and cannot ground a representation of contingent states of affairs. ${ }^{53}$ Conversely, suppose that God's knowledge of future contingents were based on ideas, then he would not be omniscient, for he would know that Socrates could be either sitting or standing up at $T$, not that he is sitting at $T$. Finally, there would be no more difference between God's knowledge of what is actual and of what is simply possible. The thrust of Scotus's criticism is his claim that being a purely intellectual, prevolitional, representation and being the representation of something contingent are incompatible properties. Since it is a natural power, God's intellect can ground neither the truth nor the knowledge of anything contingent. ${ }^{54}$

At this stage of the process, contingent propositions form pairs of contradictories which are disjunctively necessary, therefore true, but none of which is true nor false. Each member of such disjunctions is a neutral proposition that lacks a truth-value. ${ }^{55}$ This, however, does not amount to a restriction of the Principle of Bivalence $(\mathrm{PB})$, because this stage corresponds to an instant of nature, and there is no time at which contingent propositions lack truth-values. ${ }^{56}$ At this stage there are possible states of affairs and true propositions de possibili, but there are literally no contingent states of affairs nor true contingent propositions corresponding

51 to can be Bonaventure, In Sent. I, d. 38, a. 2, q. 2, concl.; d. 39, a. 2, q. 3, ooo; but also to Aquinas (De veritate q. 3, a. 1-8; In Sent. I, d. 38, q. 1, a. 3, ad. 1) and Henry of Ghent (Quodl. IX, q. 2, sol., in Opera omnia [Leuwen: 1979], XIII, 33).

52 Ord. I, d. 39, n. 7, Vat. VI, 406.

53 Ord. I, d. 39, Vat. VI, 407; Lectura I, d. 39, n. 21, Vat. XVII, 485.

54 Ord. I, d. 38, q. 1, n. 9, Vat. VI, 306. Ord. I, d. 39, n. 14, Vat. VI, 416: "quidquid intellectus intelligit hoc modo [i.e. ante omnem actum voluntatis], intelligit mere naturaliter et necessitate naturali."

55 Scotus speaks of a complexio neutra: see Ord. I, d. 39, n. 23, Vat. VI, 428; Lectura I, d. 39, n. 44, 62-65; 75, 90; Rep. I A, d. 38, q. 1-2, n. 37, ed. Söder, 233.

56 See A.J. Beck, "Divine Psychology and Modalities: Scotus's Theory of the Neutral Proposition," in John Duns Scotus: Renewal of Philosophy, ed. E.P. Bos, 123-37. At 136ff., he discusses a similar objection from Gregory of Rimini, Lectura I, d. 38, q. 2, a. 2, ed. D. Trapp - V. Marcolino (Berlin: 1981) III, 281. 
to them. This alethic (and a fortiori ontological) indetermination entails an epistemic indetermination: in the first instant of nature, God has no determinate knowledge of what is contingent. ${ }^{57}$

It may be remarked that Scotus is not very explicit on the combinations of simple states of affairs. Compossibility is the fundamental relation. Since it is defined in terms of non repugnantia alone, it is not a transitive relation (i.e. it is possible that $A$ is compossible with $B$ and $B$ compossible with $C$ and yet $A$ is not compossible with $C$ ). Compossibility alone is therefore not rich enough a relation to partition all possible states of affairs into maximal collections of states of affairs, or possible worlds. At this level, there seem thus to be possible situations, but not what we would call possible worlds. There is however a privileged class of states of affairs, those that get actualized through God's choice. This can be described as a complete possible situation and Scotus sometimes uses the phrase ordo rerum to characterize it. Therefore at least the actual world is similar to a possible world. Moreover, Scotus sometimes speaks of various ordines rerum each corresponding to some hypothetical exercise of God's ordained power. ${ }^{58}$ Though this might look a bit speculative, one could interpret that as the tacit recognition that just as the states of affairs constituting the actual ordo rerum are selected through God's will, the other ordines are defined by which states of affairs God could decide to co-create. In this respect, it is not inappropriate to see Scotus's modal framework as an anticipation of modern possible world modal semantics and metaphysics. ${ }^{59}$ Just as God's intellect constitutes the ontological ground to his knowledge of necessary truths, his will is the root of his knowledge of contingent truths. This means that God produces some states of affairs in a "willed being" (esse volitum) which only actual states of affairs enjoy, and that he determines through his will which contingent propositions are true, and which are false. He decides to actualize one of the states of affairs corresponding to any pair of contradictory neutral propositions. By actualizing such a state

57 Rep. I A, d. 38, q. 1-2, n. 37, ed. Söder, 233.

58 Talking about the nature of God's ordained power, Scotus claims for instance in Ord I, d. 44, q. un., n. 8, Vat. VI, 366: "fieret ordinate secundum alium ordinem, quem ordinem ita posset voluntas divina statuere sicut potest agree." This alius ordo is clearly a maximal collection of compossible states of affairs.

59 See D.C. Langston, God's Willing Knowledge and S. Knuuttila, Modalities in Medieval Philosophy. I would share C. Normore's verdict: "although one can find the ingredients in Scotus's picture for talking about possible worlds, the notion would do little or no work within that picture itself" ("Duns Scotus's Modal Theory," 155). See below, section 12, for additional reservations. 
of affairs, God's will makes the corresponding proposition true, and its contradictory false. God's will is thus somehow the truth-maker of every true contingent proposition. ${ }^{60}$ It is an appropriate truth-maker, since it is a rational power: while he wills that some proposition $p$ is true, he could at the same time will that $p$ is false. Let us summarize through an example: eternal happiness and its negation are both compossible with Peter's essence, and so in a first instant of nature, God knows that it is possible that Peter is happy, and that it is possible that Peter is miserable. Then, in a second instant of nature, God decrees that Peter should be granted eternal happiness, thereby making true "Peter will be happy." Finally, in a third instant of nature, God knows through his intellect that Peter will be happy. ${ }^{61}$ In the three versions of his commentary on Sentences I, d. 39, Scotus adds a modified version in order to avoid the charge of introducing discursivity within God's intellect, which would compromise the latter's simplicity. In the second version, God does not infer knowledge of contingent propositions on the basis of the knowledge of his own decrees. ${ }^{62}$ Rather, while he decrees that $p$ rather than not- $p$ is true (for contingent $p$ ), his essence represents ipso facto the truth of $p$ and is the whole ratio cognoscendi of any such truth. ${ }^{63}$

The solution proposed by Scotus to the Source question seems straightforward, but when we turn to the Reconciliation problem, matters become

60 The phrase esse volitum appears in Ord. I, d. 39, n. 31, Vat. VI, 439. On God's will as a truth-maker for contingent truths, see Ord. I, d. 39, n. 23, Vat. VI, 428: "voluntas eligens unam partem... facit illud esse determinate verum 'hoc erit pro $a$ ' "; ibid. Vat. VI, 429: "posita autem determinatione voluntatis divinae, iam sunt vera in illo secundo instanti"; n. 30, Vat. VI: "voluntas divina, determinans 'fore'alicuius ostensi ab intellectu, facit complexionem talem esse veram." Cf. Rep. I A, d. 38, q. 1-2, n. 39, ed. Söder, 234: "voluntate acceptante alteram partem contradictionis determinate, facta est unio in esse volito istorum terminorum contingentium... et complexio vera determinate." As Beck ("Divine Psychology and Modalities," 130) rightly observes, truth is an absolute notion and God's will is factive, so that what God decrees is actual and therefore true. This means that what is merely possible is, strictly speaking not true.

61 Ord. I, d. 39, n. 23, Vat. VI, 429; n. 30, 437; Cf. Rep. I A, d. 38, q. 1-2, n. 37, ed. Söder, 234: "et ideo veritate causata in complexione... per actum voluntatis, intellectus divinus tunc primo novit unam partem contradictionis contingentium esse veram."

62 Ord. I, d. 39, n. 23, Vat. VI, 428: "quasi ex intuitione determinationis voluntatis et immutabilitatis eius concludat hoc fore."

63 Lectura I, d. 39, n. 65, Vat. XVII, 501; Ord. I, d. 39, n. 23, Vat. VI, 428-29; Rep. I A, d. 38, q. 1-2, n. 38-43, Söder, 234-35. 
much more complicated. Suppose that God has decreed that $p$ (e.g. "Agent $S$ wills $A$ at $T^{\prime \prime}$ ), and thereby foreknows it. If the agent is free, this seems to entail that he could exercise his power of not willing $A$ at $T$. But then, either he would do something contrary to God's knowledge which would threaten his infallibility, ${ }^{64}$ or God's decree that $p$ would not be a sufficient condition for his knowing that $p$. William Ockham argued that the theory leads to a dilemma: either God's decree is a sufficient condition for God's knowledge, but then no one's act is necessitated by it, and it is not possible to act contrary to what one actually does; or one is free and then God's knowledge is not secured by the determination of his will. ${ }^{65}$ The synchronic theory of contingency guarantees that $p$ is contingent in itself, insofar as it proceeds from an ever-present decree of God. However, this contingency is just an effect of God's contingent willing, who, or so it seems, is the only being endowed with actual free will. Thus Scotus's theory, though it leaves room for some of contingency, ${ }^{66}$ would rule out the existence of created free will satisfying the conditions set out by Scotus. This has led some Scotus scholars to suspect that his theory is inconsistent. ${ }^{67}$ According to others, the theory is consistent, because Scotus is in effect a proponent of (theological) determinism. Appearances notwithstanding, Scotus would not develop a libertarian notion of free will, and the notion of a power for contraries must be understood as requiring nothing more than a mere ability (or even the mere logical possibility) to act in a contrary way. ${ }^{68}$ Finally, some others embrace a diametrically opposed interpretation and maintain that Scotus is a full-blown libertarian with respect to human free will. But then, one is obliged to answer Ockham's challenge on Scotus's behalf. 69

64 See Ord. I, d. 39, n. 24, Vat. VI, 429-30; Rep. I A, d. 38, q. 1-2, n. 44, ed. Söder, $235^{-3} 3$.

65 William Ockham, Ordinatio, I, d. 38, q. un., Opera Theologica (New York: 1979) IV, 582 .

66 Ord. I, d. 39, n. 24, Vat. VI, 430: "voluntas determinate volens hoc, contingenter vult hoc"; n. 31, Vat. VI, 438; n. 33, Vat. VI, 440-41. God's knowledge is not necessary, because it depends on his contingent decrees.

67 W.L. Craig, The Problem of Divine Foreknowledge and Future Contingents from Aristotle to Suárez (Leiden et al.: 1988), Chapter 5, esp. at 145; H. Schwamm, Das göttliche Vorherwissen bei Duns Scotus und seinen ersten Anhängern (Innsbruck: 1934).

68 In recent scholarship, D. Langston has defended such a view in God's willing Knowledge. Langston believes that Scotus's notion of freedom involves two claims: (i) the agent has the ability to perform $A$ and the ability to refrain from $A$; and (ii) the agent wills the performance (or the refraining) in accordance with his nature.

69 In "Does Scotus Need Molina," E. Dekker argues that Scotus is a consistent libertarian by denying that Scotus even tries to answer the Source question. For other, recent, libertarian 
In order to grasp Scotus's solution to this dilemma, one needs to turn to the problem of God's foreknowledge of evil actions or sins. This problem is extensively discussed in other passages, especially in the commentary on Sent. II, d. $37 \cdot{ }^{70}$ Scotus discusses a strongly libertarian and incompatibilist position, which the Vatican editors ascribe to Peter John Olivi. ${ }^{71}$ The core thesis is the affirmation that the will can be free only if it is absolutely undetermined, in other words, only if it is a causa totalis et immediate respectu suae volitionis. The position discussed by Scotus holds thus the following claim:

If agent $S$ has it within his power to will $A$, then there cannot be a causal requisite $R$ of $S^{\prime}$ willing such that (i) A cannot occur without $R$ 's causing and (ii) $R$ is not within $S^{\prime}$ power.

Armed with this principle, Olivi argues that if God's willing were a condition satisfying (i) it would also satisfy (ii), and therefore exclude $S$ ' freely willing. The reason is that God's will exists eternally so that our temporally limited willing could not control it. Scotus concedes that Olivi's position provides an easy answer for excusing God from the responsibility of evil. ${ }^{72}$ But it cannot be reconciled with the exclusive role of God in predestination, and more generally, with the idea of hierarchy of causes. Moreover, it would undermine the infallibility of God's knowledge of future contingents, if it is based on God's knowledge of his own decrees. This leads Scotus to provide an alternative account. In order to achieve that, he uses the device of partial causes cooperating to produce a single effect. ${ }^{73}$ There is nothing new to the idea that God's action is necessary to sustain the created world's existence and causal activity within it. What is distinctive of Scotus's position is the way he integrates his account within a general theory of partial, cooperating causes. ${ }^{74}$ In general, he distin-

interpreters, see A. Vos et al. Contingency and Freedom, and W.A. Frank, "Autonomous Freedom and Divine Co-Causality," Medieval Philosophy and Theology 2 (1992): 142-64.

70 See A.B. Wolter, "Scotus' Paris Lectures on God's Knowledge of Future Events," repr. in Wolter, The Philosophical Theology of John Duns Scotus, ed. M. McCord Adams (Ithaca: 1991), 285-333 and W.A. Frank, "Autonomous Freedom."

71 Peter John Olivi, Summa II, q. 116, in corp. quoted at Vat. VIII, 408-o9.

72 Ord. II, d. $34-37$, q. 5, n. 113 , Vat. VIII, 415.

73 Ord. II, d. $34-37$, q. 5, n. 117 and n. $142-43$.

74 The theory first appears at Ordinatio I, d. 3, p. 3, q. 2, n. 496, Vat. III, 293, where he treats the respective roles of the perceived object and the intellect to produce an actual 
guishes three ways distinct causes might be ordained in the production of a single effect. Accidentally ordained causes are such that a single cause could independently produce the whole effect if its power were intensified, as when two horses are needed to pull a cart, one of them could nevertheless suffice, provided he were strong enough. The next two cases concern essentially ordered causes. Sometimes, the causal activity of the subordinated cause is wholly consequent upon the first cause's activity. This happens when, for instance, the hand moves a staff: the staff has no motion of its own, but only as it is acted upon by the hand. ${ }^{75}$ Finally, the two causes sometimes play an essentially distinct and complementary causal role, though one is ontologically superior to the other. As an example, Scotus mentions the generation of a child, which requires the actions of both the father and the mother as its immediate causes, though the male is considered as intrinsically superior to the female.

In the present case, God and the created will can be considered as two partial cooperating causes of the third kind. Contrary to Aquinas's account, God's will does not act directly on the created will, but cooperates with the latter in order to produce a single volition. From this point of view, the actualization of a causal power does not need the influence of the first cause, except for its sustaining in existence. This remains vague, however, for God's primacy could still imply some way of determining the created will's causation. But God would be guilty of sin if his causation were the root of the deficiency constitutive of the sinful action. With the help of this idea, Scotus develops his own solution to the problem of God's concurrence to sin. It is worth quoting at length:

Thus, if the created will and the divine will concur to the created will's willing, there can be a defect in the willing itself due to the defect of one of the two causes. And because this cause could give rectitude to its act, and is bound to give, but nevertheless does not, while the other cause, though it is not bound to give it, nevertheless "so far as it is in itself" (quantum est ex se), would give it, if the created will were to cooperate. Indeed,

cognition and then again. In Lectura II, d. 25, n. 71-73, Vat. XVII, 253-54, Scotus pictures the intellect and will in the production of a volition as two partial, cooperating causes. See above n.

75 Interestingly, this is the analogy used by Aquinas to explain God's causal influence on the secondary causes in order that they produce their effects; see, SCG III, $67-70$ and De potentia, q. 3, a. 7, in corp. and ad. 15. According to Aquinas, God's causal activity is participated by the creatures, and thus, one may say that the creatures' causal activity is actuated by God, acting as a first cause. Any created agent acts through the power of the first canse hy participation of its causal power. God's and creatures' causal contribution do not $\square$ as homogeneous concurring causal factor. 
everything God gave antecedently, He would give consequently (so far as it is in Himself), unless there should be an impediment. By giving to the free will, He gave antecedently the right works (opera recta) which are within the will's power. And thus, as for His part, He gave rectitude to every act of will-and He would give consequently to the will, if the will itself were to cause rightly any elicited act as for its part (ex parte sui).... The superior cause quantum est ex se would cause, if the inferior would cause according to its own causality (Ord. II, d. 34-37, q. 5, n. 143-44, Vat. VIII, 428-29).

According to this passage, neither evil acts would occur without a created will's causality, nor righteous action without God's concurrence. To understand the whole process, one needs to start from the will's power for opposites. (i) If $S$ actualizes her power for $A$, and $A$ is right, God would concur with $S$ by producing the needed rectitude in $A$. But (ii) if $S$ actualizes her power for not- $A$, then God would not concur with $S$. As a consequence, $S$ ' action would not be right nor meritorious, and $S$ would sin, because he could have chosen to actualize $A$ instead. The combination of (i) and (ii) entails a kind of counterfactual dependency of God's will (which is presupposed by his concurrence and foreknowledge) upon the created will's choice. In case (i), God wills that $A$, whereas in case (ii), God is said only to permit $A$. This dependency is asymmetrical, for it is not required in the case of the meritorious actions of the predestined, but only to explain how one can excuse God from any responsibility for sin. One might wonder if the discussion of this issue does not rest on a different account of foreknowledge from the one explicitly developed earlier. Indeed, according to Scotus:

(1) If $S$ is free and wills $A$, then (i) God eternally foreknows that $S$ wills $A$ and (ii) if $S$ had not willed $A$, God would have foreknown that $S$ does not will $A$.

If one maintains that foreknowledge is based on a divine decision, then (ii) amounts to:

(1') (ii') If $S$ had not willed $A$, then God would have decreed that $S$ does not will $A$.

But then there seems to be a covariance of God's decrees with the creatures'. If one reminds that God's decrees, being eternal, never fade into past, and remain forever contingent, one might conclude that the power not to will $A$ remains within $S^{\prime}$ power even if it is foreknown that $S$ shall 
will $A$. Scotus's position as it is exposed in this passage is consonant with a form of libertarianism, though not of the extreme incompatibilism defended by Olivi. He would modify the latter's condition for freedom, by revising the power condition: some requisite might be such that they are neither within the will's power nor independently given. This new account has the advantage of rendering God's foreknowledge and the will's freedom compatible, and enabling to answer Ockham's challenge. The trouble is that, though not inconsistent with the "official" view, this account departs from the latter's greater intelligibility as a theory of how God knows future contingents. For such an infallible covariance without any dependence of God's will upon knowledge of the creature's decisions runs the risk of looking either as something like a cosmic coincidence or a pure mystery of faith. ${ }^{76}$

We are now in a position to grasp Molina's relation to Scotus's thought. To begin with, I shall examine Molina's conception of free will and divine concurrence, where Scotus's influence is most explicit. Then I will examine the criticisms raised by the Jesuit against the Subtle Doctor against the latter's account of foreknowledge. Finally, after a brief examination of Molina's theory of foreknowledge, I will try to assess, beyond the apparent points of agreement and criticisms, the deep-level relations between these two thinkers.

Molina's definition of free will (liberum arbitrium) clearly has Scotist roots. Both consider the will as both the locus and the source of freedom, against the preeminence of the intellect, which characterizes the Thomistic

\footnotetext{
76 Whatever its obscurities, many theologians of the Renaissance, under the influence of Scotus, articulated such a theory of concomitant decrees. Among others, the Franciscans Antonio de Cordoba and Andrés de Vega proposed such views. Cf. Antonio de Cordoba, Quaestionarium theologicum, I, q. 55, dub. $¥-12$, Andrés de Vega, Tridentini decreti de

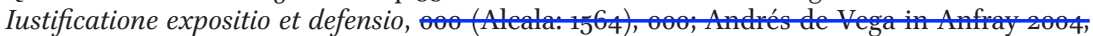
2. 5.5 . According to the latter, if the will is free, then if $S$ wills $A$, then God has decreed that $S$ would will $A$, but $S$ has the power not to will $A$, and if he actualized this power, then God would have eternally decreed that $S$ would not have willed $A$. Among the Jesuits, Gabriel Vázquez seems to have developed an answer to the foreknowledge dilemma based on such concomitant decrees
} 
tradition. ${ }^{77}$ Will is a free cause according to Molina. ${ }^{78}$ It enjoys a freedom from necessity which is defined in the following way:

That agent is free, which, when all requisites for acting are present, can act and not act, or act in such a way that it can equally act in a contrary way. And it is because of such a freedom that the faculty through which such an agent can act this way is said to be free.... And free will (liberum arbitrium)... is nothing else but the will, which is formally free according to our definition, when it is preceded by a judgment of reason (Concordia, disp. 2, n. 3, ed. Antwerpen, 8a).

Although Molina does not give up the requirement of rationality in order that a being be free, his definition shows that the essential property of a free agent is that her actions do not occur deterministically. That is to say, if agent $S$ is free, then there is no set of requisites $R$ prior to $S$ 's choosing some course of action $A$ such that $R$ entails that $S$ wills that $A$. This is Molina's way of understanding freedom as a potestas ad opposita, a power for opposites. ${ }^{79}$ Molina's insistence on the fact that such a power is to be understood in sensu composito shows that free will does not involve a simple ability flowing from the nature of the agent, but also the presence of a real opportunity. For instance, someone who is constantly chained to a seat during an interval of time $T$, thereby loses her power to stand up and is therefore not free during $T .^{80}$ On the contrary, if she desires to sit

77 Concordia, disp. 2, n. 9. I will quote from A.J. Freddoso's translation when possible. In other cases, I will refer to the second edition of the work in the Antwerpen edition of 1595 .

78 Concordia, disp. 24, n. 8.

79 Concordia, disp. 2, n. 3; cf. disp. 53, memb. 2, n. 17.

80 D. Langston acknowledges this, and considers that Molina departs from Scotus on this score (see God's willing Knowledge, 67). But one must be cautious here, for if some situation $H$ is such that one would certainly choose some definite course of action, one does not lose one's freedom, if some distinct agent actualizes and maintains situation $H$. If I were presented a box of chocolate, I would take one, but I do not lose my free will just because I am repeatedly offered some, and do not decline any. Molinist free will entails the power to will the opposite of what one actually wills in certain circumstances, not the power to control the circumstances where one finds himself into. The theory of middle knowledge (infra) rests on this idea: an agent, having both the ability and the opportunity to will the opposite in a situation $H$, is such that if placed in $H$, he would (freely) do $A$ and some agent, say God, knows this and has the power to ensure that $S$ is placed in $H$. Moreover, one could exploit this idea to reinterpret some passages where Scotus claims that the blessed in heaven are free to love God, though he prevents them from sinning (Ord. IV, d. 49, q. 6, n. 11, Wadding X, 455). According to Langston the situation is analogous to the case where someone is chained to a seat and, while having an ability to stand up, is deprived of the opportunity to do so (God's willing Knowledge, 40-41, 50, and 122-23). Scotus's own example of the eye retaining the power to see the sky, in spite of the presence of a perpetually intervening obstacle, apparently comforts Langston's interpretation. But it is possible 
and sees that there is nothing wrong to this, then she is free only if these psychological (and other causal) requirements do not entail that she will sit, but leave it open for her to stand up. This feature explains why Molinist freedom is also called freedom of indifference, which means that the motives presented by the intellect do not determine the will to its choice. ${ }^{81}$ Molina argues as Scotus did, that the existence of free will is a matter of psychological experience and cannot be rationally denied. ${ }^{82}$

Finally, Molina subscribes to Scotus's idea of a non-evident power of the will to simultaneously will $A$ and not will $A$. This is the central thrust of disputation 24 of the Concordia, where Molina overturns Ockham's arguments against the idea of a synchronic power for opposites. Ockham had objected to Scotus's non-evident power for opposites, that it entails a denial of the law of contradiction and refused to countenance instants of nature. According to Ockham, one is free to will either of two contradictory courses of action before the time $T$ when the volition is elicited. But at $T$, if one wills $A$, this makes refraining from $A$ impossible. In other words, dual possibility is essentially forward-looking. ${ }^{83}$ According to Molina, this entails that one is free just before one acts, but not at the time when an act is elicited. Since he assumes that one is responsible for an act $A$ occurring at $T$, only if one is free at $T$, he infers that Ockham's denial of the Scotist simultaneous power for opposites leads to a denial of responsibility. Moreover, Molina rehearses Scotus's case of the angel existing for a single instant of time, or of the actual angels at the moment of their creation. ${ }^{84}$ According to Molina, such an angel is free at this moment, otherwise he could not be responsible for what he does. He avoids falling into contradiction by using the Scotist device of the distinction of many instantia naturae within a single temporal instant. ${ }^{85}$ While he wills $A$ at $T$, such an angel must also have at $T$ the power to refrain from $A$. This power

to understand Scotus differently (by extrapolating a bit from Scotus's final answer ibid. n. ${ }_{15}$, Wadding X, 457), if one considers it as a situation where God constantly maintains the situation under which he knows that the blessed will freely avoid sinning. The distinction here is very like the one proposed by Freddoso, 26-28.

81 See Concordia, disp. 2, n. 6, Antwerpen, 8b and n. 9, Antwerpen, ga.

82 Concordia, disp. 23, memb. 1, Antwerpen, 89b-90a.

83 Ockham, Ordinatio, I, d. 38, q. un., OTh IV, 581.

84 Concordia, disp. 24, n. 6; see Schmutz, "Du péché de l'ange à la liberté d'indifférence," for a much more detailed historical analysis of this point.

85 Concordia disp. 24, n. 8. Such instants are officially distinct by a distinction of reason, for Molina clearly says elsewhere that it is: "priority in our way of conceiving it, but with a basis in reality" Concordia, disp. 53, pt. 1, n. 20, trans. Freddoso, 211. However, when he uses the device of instants of nature in the case of volition, he seems to abandon this view. 
is related to an earlier instant of nature $N 1$, while the elicited volition is related to a later part of $T, N_{2}$.

However, the two thinkers' positions are only superficially identical on this score. The latter, considering the temporal instant as a whole, maintains that the present is contingent and sees the order of instants of nature as a logical order that does not constitute a parallel quasi-temporal order. On the other hand, according to Molina, the order of natural priority seems to be a discontinuous and irreversible order. He grants that the will is free at $N 1$ to will $A$ and not to will $A$. But once its choice, say $A$, is considered as elicited from the point of view of $N_{2}$, the power to refrain from $A$ is destroyed, and it becomes necessary that $S$ wills $A .^{86}$ It could thus be seen as a more fundamental quasi-time order. Therefore, Molina is better seen as downplaying the Aristotelian thesis of the necessity of the present, rather than rejecting it outright, as Scotus does.

\section{VIII}

The idea of God's general concurrence with created secondary causes is another aspect of Scotus's influence on Molina's thought. ${ }^{87}$ Scotus's conception is an alternative to that of Thomas Aquinas, according to whom creatures act as secondary causes only by participation to God's causation. On the contrary, as we have seen earlier, Scotus conceives their respective contribution on the model of concurring partial causes producing a total effect. The central tenet of this new paradigm is that God does not act on the secondary cause to produce the effect, but God cooperates with the created cause in order to produce a single, unified effect. Molina sides with Scotus against the Thomistic account. He objects to the latter that it is based on the mistaken idea that creatures' causal powers are essentially incomplete and thus need a kind of motio from their first cause. However, this would ruin the very possibility of distinguishing a causal power, be it natural or free, from a mere requisite. What distinguishes the former is that they are complete. Therefore, God is a partial, concurring cause, along with the created cause. He is absolutely necessary in the sense that

\footnotetext{
86 Concordia disp. 24, n. 5, 9, and 11.

87 Concordia disp. 25-28 and the 1572 Quaestio de concursu generali in Geschichte des Molinismus. Bd. I. Neue Molinaschriften, ed. F. Stegmüller (Munster: 1935). More on this in J. Schmutz, "La doctrine médiévale des causes et la théologie de la nature pure (XIII $-\mathrm{XVI}{ }^{\mathrm{e}}$ siècles)," Revue thomiste 1-2 (2001): 217-64. In the Concordia disp. 35, Antwerpen, 1595, 146b, Molina explicitly refers to Scotus, Ordinatio IV, d. 1, q.
} 
no effect could occur without his causal contribution. However, he does not determine by himself the nature of the effect. Rather, God's causation is more like a general power, which is determined when it is conjoined with a secondary cause's causation. ${ }^{88}$ This is the reason why God's concurrence is characterized as "indifferent." 89 Thus not only does Molina give up the Thomistic model of the structure of action, he also presents an altogether different account of its modality. This is particularly important in the case of created free causes: given God's concurrence with agent $S$, it is both possible for $S$ to will $A$ and to refrain from willing $A$. In other words, Molina includes God's concurrence among the requisites relative to which the will is indifferent.

What is remarkable is that, while the theory has clear antecedents within Scotus, Molina uses it in order to argue against another central Scotist thesis, namely that God's will is the root of contingency. He devotes the whole of disputation 35 and part of disputation 47 to refute this last claim. He rehearses Scotus's threefold argumentation, from the transitivity of causal necessity; from the primacy of the first cause with respect to the created effect; and from-on the causal sufficiency of the first cause. Molina claims that all these arguments are unconvincing. The last two entail that God is the only contingent cause, and therefore lead to theological determinism. The first argument is incompatible with the theory of concursus indifferens, which has two consequences. First, under the impossible assumption that God were acting as a necessary (i.e. natural) agent, there would nevertheless remain contingency within the world. ${ }^{90}$ The reason is simple according to Molina: since the effect cannot occur if one of its partial causes does not produce part of its work, then, even if one cause acts necessarily, the effect would not occur if the other did not act. The theory of general concurrence neutralizes so to speak the modality of God's action. Conversely, if God were acting as a free agent, but there were no other, created free agents, then,

\footnotetext{
88 See A.J. Freddoso "Introduction," in Luis de Molina, On Divine Foreknowledge: Part IV of the Concordia (Ithaca: 1988), 17.

89 Molina, Quaestio de concursu generali, ed. Stegmüller, 199: "concursus Dei universalis nihil aliud est, quam influxus Dei immediatus in omnes effectus."

90 Concordia, disp. 35, Antwerpen, 1595, 147a: "esto necesario moveatur, non tamen necessario movere, quando motus quem recipit, neque est tota, neque sufficiens causa eius motus, qui ab ipsa emanare debet, sed adhuc ad eum necessaria est, tanquam pars causae libera cooperation et influxus causae ita motae. quare esto per impossibile Deus necessitate naturae influeret eadem auxilia gratiae, quae reipsa confert, maneret nihilominus libertas in voluntate nostra."
} 
that God does not act miraculously, all effects that do not immediately depend on God's causal activity (i.e. events like the creation of the world, the Incarnation, etc. $)^{91}$ would happen with a fatal necessity, because all secondary free causes would have been removed. ${ }^{92}$ This kind of necessity is defined by Molina as a causal modality, one that results when the occurring of one event is deterministically entailed by the existence of a chain of earlier events. ${ }^{93}$ Thus according to Molina, causal modalities, contrary to logical modalities, are not absolute nor are they relative to God's causal contribution, but they are relative to the order or secondary causes: $E$ is naturally contingent if $E$ is the effect of a contingent, secondary cause (i.e. a free cause). ${ }^{94}$ Therefore, God cannot be the root of contingency within the world, though it may be conceded that he is its remote source insofar as he freely decided to create the world. The theory of general concurrence leads Molina to a position that is superficially similar to the position criticized by Scotus, namely that there can be contingency within things even if the first cause is necessary. The similarity is superficial, because those criticized by Scotus were mostly determinists, or at least they considered that contingency was a kind of imperfection, deriving from the imperfection of secondary causes. As we have seen, Scotus treats contingency as a mode of being, on a par with necessity, and Molina shares the same point of view. ${ }^{95}$ their understanding of the role of divine will. For Scotus, it is the ultimate root of any contingency, while Molina grants that there are as many quasi-independent roots of contingency as there are free causes. He is led to this position by splitting two closely connected Scotist theses, namely, that God's will is the root of contingency, and that God and creature act as essentially ordered cocauses to produce a single effect. While he develops the latter as one of the cornerstones of his thought, he thinks that the first is clearly incompatible with it. He is thus led to claim that Scotus is essentially incoherent.

91 Concordia, disp. 47, n. 4, see Freddoso "Introduction," 20-21.

92 Concordia, disp. 47, n. 9.

93 Concordia, disp. 47, n. 2; notice that, as remarked by Freddoso at note 19 on p. 94 of his translation, the causal necessity of the occurring of any event presupposes as a condition that God does not miraculously suspend his general concurrence; see also disp. 47, n. 12.

94 Concordia, disp. 47, n. 10.

95 Scotus, Ord. I, d. 39, n.35, Vat. VI, 444: "contingentia est modus positivus entis (sicut necessitas est alius modus)... immo contingentia per prius est a causa prima quam secunda." Cf. Ibid., n. 13, Vat. VI, 414-15. 
IX

The treatment of Aquinas's theory of God's foreknowledge of future contingents as based on their presence to God in eternity is indeed another instance of Molina's complex relationship to Scotus. On the one hand, he defends the coherence of the idea of successive events coexisting in eternity and so he seems to counter Scotus's own arguments against Aquinas, which are rehearsed at the beginning of disputation 48. Significantly, he accuses Scotus of overlooking the fact that the present tense locution " $E$ coexists with Eternity" may connote either the now of time or the now of eternity. ${ }^{96}$ Thus when Scotus claims that coexistence cannot relate events occurring at successive moments of time $T$ and $T$, he thinks that " $E$ coexists at $T$ with $E^{*}$ expresses Aquinas's thesis. But this sentence is plainly false, and " $E$ coexist in eternity with $E^{*}$ " is the correct expression of Aquinas's thesis. Thus it might seem that Molina opposes Scotus on this score.

However, Molina is much closer to the Subtle Doctor's conception of time and eternity than it might seem. First of all, he rejects Aquinas's theory as a sufficient explanation of God's foreknowledge. His objections reflect the same conceptions as those underpinning Scotus's own objections. A first argument establishes that the presence of things in eternity cannot account for God's knowledge before his decision to create the world, for either such knowledge is based on God's knowledge of his own intentions, or things would exist in eternity independently of God's decisions which would preclude the exercise of any providence. ${ }^{97}$

Another argument is directly inherited from Scotus: if the presence of things in divine eternity were sufficient to ground foreknowledge, then the angels too should be conceded foreknowledge. Molina considers the traditional answer given by the Thomists, namely that, though the aevum is an indivisible duration measuring the existence of the angelic substances, their operations, in particular, the acts of cognition, are not so indivisible, but rather successive. But as a rejoinder, Molina claims that it is possible that God conserves a single act of angelic cognition, which would be indivisible and would embrace all events.

Nonetheless, the most interesting argument starts from the idea that future events are still contingent, and so are really able not to occur.

\footnotetext{
96 Concordia, disp. 48, n. 8-9.

97 Concordia, disp. 49, n. 15; De scientia Dei, ed. Stegmüller, 227-28.
} 
Suppose that some such event does not occur, this implies that it is able not to exist in eternity. It acquires a definite existence only from the moment of its occurrence. But then it would be wrong to say that God has had an infallible knowledge of this event at any time before this moment. Using the parallel with God's immensity, Molina claims that just as God's immensity does not coexist with nonexistent places, neither does his eternity coexist with not yet existing moments. In Molina's technical vocabulary, adequate eternity corresponds to the whole of time, but this correspondence is not completed until the whole of time has elapsed. When eternity is considered as corresponding to a stretch of time, it is taken inadequately and as such, it does not coexist with what follows. ${ }^{98}$ To illustrate this, he uses Scotus's example of a circle in the process of being drawn. The center corresponds only to the points of the circumference that have been actually traced, but not the ones that are not yet drawn. This entails a dynamical conception of time, and a notion of eternity closer everlastingness than to strict atemporal duration. ${ }^{99}$ On the whole, it appears that Molina's and Scotus's views on the nature of time and eternity differ only verbally.

\section{$\mathrm{X}$}

The debate actually bears on a different issue, namely the relation between time and modality. As was shown above, Scotus does not subscribe to the Aristotelian notion of the necessity of the present. Nevertheless, he still holds that there is no power over the past. This leads him to a position on foreknowledge that bears striking similarities with the account known as Ockhamism in the foreknowledge debate. Very briefly, according to this view, the fact that God foreknows that $S$ will do $A$ is compatible with $S$ 's power not to do $A$. If $S$ actualizes this power and refrains from doing $A$ at $T$, then he brings it about that God will have foreknown from all eternity that $S$ does not do $A$ at $T$. On the traditional Ockhamist account, God's foreknowledge is indeed affected with pastness, but escapes its accidental necessity by not being a fact really about the past (what recent commentators have labeled a "hard fact"), since its content depends on what is yet

98 De scientia Dei, ed. Stegmüller, 228-29 especially "nondum adsit tempus futurum quod illi correspondeat."

99 See ibid. Craig (The Problem of Divine Foreknowledge, 172) holds to the same conclusion. 
future and thus contingent. ${ }^{100}$ The Ockhamist thus holds the following claim:

(2) God has always known that $S$ will do $A$ at $T$ and, until $T$ ( $T$ excluded), $S$ can bring it about that God will always have known that $S$ will not do $A .{ }^{101}$

If this thesis is combined with an account of knowledge based on divine decrees and the thesis of the necessity of the present, the former claim becomes equivalent to this:

(2') God decrees that $S$ will do $A$ at $T$, and, until $T$ (T included), $S$ can bring it about that God will always have decreed that $S$ will not do $A$.

This latter claim corresponds exactly to Molina's exposition of the theory of concomitant decrees:

for they maintain that if, for instance, Peter, who let us assume, is going to sin at some moment of time, did not sin at that time (which he is capable of because of his freedom) then God would bring it about that He had never known that Peter was going to sin, but that instead He had always known from eternity that Peter was not going to $\sin$ (Concordia, disp. 51, n. 1).

Molina objects to this theory on the ground that it compromises God's providence and predestination and entails the impossibility of genuine prophecies. ${ }^{102}$ But his main charge is that any version of the theory of concomitant decrees leads to a denial of the necessity of the past, and forces one to acknowledge some power over the past in God. ${ }^{103}$ The latter

100 Ockham, Ord. I, d. 38, q. un., OT IV, 588: "quando talis propositio de praesenti aequivalet propositioni de futuro vel dependet a veritate alicuius futuri, non oportet quod propositioni verae de praesenti correspondeat necessaria de praeterito. Et ita est in proposito."

101 Ibid., OT IV, 586. Molina expresses the same view in De scientia Dei, ed. Stegmüller, 242: "si ego pro mea libertate fecero hoc, Deus faciet se numquam scivisse nisi hoc, et si fecero oppositum, ut de facto possum, Deus faciet se numquam scivisse nisi oppositum." Molina attributes the view to most scholastics and to many important Tridentine theologians, especially to Antonio de Cordoba and Andrés de Vega (see above, n.

102 Concordia, disp. 51, n. 19-20.

103 The inference from the (restricted) contingency of God's foreknowledge to a generalized power over the past was highlighted in the 14th century by thinkers like Peter of Ailly and earlier by Thomas Bradwardine; see R.M. Gaskin, "Peter of Ailly and Other Fourteenth Century Thinkers on Divine Power and the Necessity of the Past," Archiv für die Geschichte der Philosophie 79 (1997): 273-91. 
is strictly impossible and we see that Molina grants a strong necessity to past states of affairs. Its medieval label is necessity per accidens: once an event has occurred, it becomes contradictory to assume that it has not. ${ }^{104}$ According to Molina, any theory along the lines of 2 or 2' entails the contingency of what is past. Suppose for instance that God decrees today that the world never existed: this would that some past events did not occur, which is absurd. ${ }^{105}$ This criticism of Ockhamism can be extended to the Scotist, eternalist, version of the theory of concomitant decrees. Even if one grants that God's present volitions never fade into the past, and therefore remain contingent, they nonetheless have real, temporally past effects. ${ }^{106}$ As a consequence, while on the one hand divine decrees are contingent if they are related to eternity taken as a whole, on the other hand they are accidentally necessary if they are referred to some portion of time. Once God's decision to create the world is actual, it becomes necessary at all later times that God has decided to create the world. ${ }^{107}$ What emerges from this is that Molina is close to the Aristotelian picture of the relations of time and modality and distances himself from the consequences of the Scotist conception.

This becomes a highly disputed issue when one turns to the Molinist treatment of the logical problem of future contingents. Interpreters are opposed on the question of whether Molina endorses or denies the Principle of Bivalence (PB) in the case of future contingent propositions. The fatalist inference discussed by Aristotle in De interpretatione, Chapter 9 (18a34-b25) starts from the premise that PB applies to all future contingent propositions, and concludes to the necessity of what will happen. One way of interpreting the argument is to see it as resting on the idea that if some proposition is true, then there is a fact it, and facts are sueh that they are unpreventable. In the case of the past, we think that is stocked with truths and this is the reason we come to believe that it is unpreventable or necessary. On the traditional interpretation, Aristotle would not deny the principle on which the fatalist inference is based, but instead restrict the scope of PB. The fatalist and the Aristotelian share the idea that there is a strict match between truth (or

104 Concordia, disp. 51, n. 12 and Commentaria in primam D. Thomae partem, q. 25, a. 4, 354a-355b. See Craig, The Problem of Divine Foreknowledge, 186-87.

105 Concordia, disp. 51, n. 14.

106 Molina's criticism anticipates C. Normore's remark that "if what is genuinely past is what is past for us, this raises the very delicate issue of wether what is in our past is really necessary or not" ("Duns Scotus's Modal Theory," 136).

107 Concordia, disp. 51, n. 25; disp. 48, n. 21; De scientia Dei, ed. Stegmüller, 244-45. 
ontological determinateness) and necessity. And Molina seems to accept the same conclusion. ${ }^{108}$ But Scotus's conception of synchronic contingency and God's will as a truth-maker for contingent propositions, at least as far as propositions on the present are considered, entails a possible gap between the two. ${ }^{109}$ Conversely, Molina's criticisms of the theory of concomitant decrees seem to rest on a fundamentally Aristotelian intuition.

We have seen above that Molina ascribes deterministic consequences to Scotus's theory of the source of contingency. He comes to same conclusion as far as the latter's account of divine foreknowledge is considered. Scotus's position is summarized in the following way:

he claims that it is solely in the determination of His will that God knows which part of each contradiction is going to turn out to be contingently true in the future, and thus that it is solely in the free determination of His will that He knows future contingents with certainty (Concordia disp. 50, n. 7 , trans. Freddoso, 132).

Such a theory is incompatible with libertarian free will. ${ }^{110}$ Suppose that $S$ is free to will $A$. Then it must be able to refrain from willing $A$. God decides to make " $S$ wills $A$ " true by bringing about the corresponding state of affairs. But this seems to entail that either $S$ is no longer able not to will $A$, or God's will would not suffice to ground an infallible knowledge.

108 Concordia, disp. 52, n. 6, n. 15 and n. 37; Quaestio de futuris contingentibus, ed. Stegmüller, 9: "si enuntiationes de futuro essent determinate verae, omnia evenirent necessario non solum necessitate consequentiae sed etiam consequentis." In this passage, Molina does not reconstruct Aristotle's position but seems to give his responsio propria. Matters are complicated by the exact "determinate." According to Craig (The Problem of Divine Foreknowledge) and Freddoso ("Introduction"), it means "necessarily" and on their reading Molina does not restrict PB, but just tries to detect a fallacy in the fatalist inference. However, it is more likely that Molina understands "determinately" as expressing the distribution of truth-values within a disjunction of contradictory sentences; see R.M. Gaskin, "Molina on Divine Foreknowledge and the Principle of Bivalence," Journal of the History of Philosophy $3^{2}$ (1994): $55^{-71}$. A given sentence is determinately true if it is true and its contradictory is false. And it is indeterminately true iff it is indeterminately false. Such a reading of the adverb "determinate" was not uncommon, for someone like Peter Aureol in the 14th century, who explicitly denies that PB applies to future contingent propositions, simply equates determinate verum and verum. Cf. Scriptum super sententias I dist. 38, art. 3, ed. Schabel, Cahiers de l'institut du Moyen Âge Grec et Latin 65 (1995): 126.

109 For Scotus's hesitant claims about the determinacy of the future, see Lectura I, d. 39, n. 69, Vat. XVII, 502-03: "sed in futuris non est determinatio talis: licet Deus determinate sciat $a$ fore pro aliquo instanti, pro illo tamen potest scire $a$ non fore"; $O r d$. I, d. 39, n. 26, Vat. VI, 432: "talis autem non est determinatio ex parte futuri, quia licet alicui intellectui sit una pars vera determinate... non tamen ita quin in potestate causae est pro illo instanti ponere oppositum."

110 De Scientia Dei, ed. Stegmüller, 238; Concordia, disp. 50, n. 7, n. 14. 
Now, Molina makes up a possible, compatibilist answer glthough "God wills that $S$ wills $A$ and $S$ does not will $A$ " expresses an impossible proposition fin sensu composito $)$, yet it is possible in sensu diviso that $S$ does not will $A$. Molina is reluctant to countenance the of the distinction in such a case, because there are two types of conditional necessity of the form "necessarily (if $P$, then $Q$ )." If the antecedent $P$ is such that if someone $S$ has the power to bring it about that $Q$ is not true, then $S$ has the power to bring it about that $P$ is not true either, we can consistently maintain both "it is impossible that $P$ and not- $Q$ " and " $S$ has the power to make not- $Q$ true." If, however, the truth of the antecedent is beyond the scope of $S$, then it should be denied that $S$ has the power to make not- $Q$ true..11

In the Concordia, Molina introduces the theory of a thorough Thomist like Domingo Bañez (1528-1604) as a mere verbal variant of Scotus's own theory. ${ }^{112}$ This gives him an occasion to discuss a problem which Scotus struggled with, as we saw above, namely, how an account of divine foreknowledge based on divine decrees avoids the pitfall of either making God the author of sin or rendering him uncertain about bad events. ${ }^{113}$ Bañez's own answer introduces a clear asymmetry: God knows that $S$ sins when he refrains from willing that $S$ acts righteously. But as we saw above, Scotus considered that this cannot provide a secure basis for God's infallible knowledge, unless one claims that any free creature, if left to her own resources, will inevitably sin. But this last concession entails the denial of free will and responsibility. The as an extreme version of Scotus's account of foreknowledge, which confirms that he interpreted the latter as a deterministic theory.

111 De scientia Dei, ed. Stegmüller, 238; Concordia, disp. 50, n. 9; Molina's distinction is similar to the Anselmian distinction between necessitas antecedens and necessitas sequens. Cf. Anselm, Cur Deus homo II, 17, Opera omnia, ed. F. Schmitt (Stuttgart: 1966), II, 125. See Suarez, De gratia, prol. 2, c. 7, § 20 (1st ed. 1619), Opera omnia, ed. C. Berton (Paris: 1856-77) vol. VII, ooo.

112 Concordia, disp. 50, n. 8, trans. Freddoso, 134: "A certain disciple of St. Thomas, differing only verbally from Scotus, attributes the same position to St. Thomas." See D. Bañez, Scholastica Commentaria in universam primam partem angelici Doctoris D. Thomae, q. 14, a. 13 (Venice: 1602), 449E: "Deus cognoscit futura contingentia per rationes ipsorum que sunt in Doe, idest per ideas proprias, quae sunt in Deo futurorum contingentium, sed idea repraesentat certo et infallibiliter per modum exemplaris et efficientis"; 45oC: "idea quantum ad actualem existentiam creaturarum et quo ad alia praedicata contingentia, non repraesentat naturaliter et necessario simpliciter loquendo sed tantum in sensu composito, idest supposita libera divinae, voluntatis determinatione circa ipsos effectus creatos."

113 Concordia, disp. 50, n. 10-13. 
Molina's own positive account of divine foreknowledge constitutes of course an essential element in order to appraise his relationship to Scotus. As this aspect of his thought is treated elsewhere in the volume, I will give only a rough sketch. ${ }^{114}$ Molina's central innovation consists in the introduction of middle knowledge (scientia media) as an intermediary stage in the divisions proposed by Scotus and Aquinas. The former distinguished God's natural knowledge of what is necessary and his free knowledge of contingent states of affairs. Middle knowledge falls between the natural and the free knowledge. Like Scotus, Molina describes God's natural knowledge as the knowledge, based on the contemplation of his own essence, of what is possible. ${ }^{115}$ Natural knowledge and free knowledge are characterized exactly as Scotus did: the content of the former includes all necessary states of affairs and lies beyond the scope of God's power. God has free knowledge of what he decrees to create. It is free because (i) it could have a different content and (ii) such a change depends on God's will (Concordia, disp. 52, n. 9). Middle knowledge is then added to this dichotomy in order to save creaturely freedom as well as God's providence and predestination. According to Molina, God knows any decision, not only what is possible under any hypothesis considered, but also what creatures would do in any situations, in particular, what humans would freely do under such or such a hypothesis. ${ }^{116}$ Through his middle knowledge, then, God knows not actual future contingents, but what Molina calls conditional future contingents (FCCs):

All contingent states of affairs are, I repeat, represented to God naturally, before any act or free determination of the divine will; and they are represented not only as being possible but also as being future-not absolutely future, but future under the condition and on the hypothesis that God

114 Freddoso ("Introduction," 46-62) and Craig (The Problem of Divine Foreknowledge, Chapter 7) provide entries in Molina's version of the doctrine. For later developments within Jesuit theology, see S.K. Knebel, "Scientia Media. Ein Diskursarchäologischer Leitfaden durch das 17. Jahrhundert," Archiv für Begriffsgeschichte 34 (1991): 262-94. For an introduction to middle knowledge discussions within contemporary philosophy of religion, see E. Dekker, Middle Knowledge (Leuwen: 2000).

115 De scientia Dei, ed. Stegmüller, 239; God's essence is the primary object of his knowledge; see Concordia, disp. 50, n. 16.

116 Evidence for the reality of such a knowledge is given by the biblical story of David and Saul at Keilah (1 Sam. 23:10-12), and Jesus's lamentation at Chorazin and Bethsaida (Matt. 11:21). 
should decide to create this or that order of things and causes, with these or those circumstances (Concordia, disp. 50, n. 15, trans. Freddoso, 140).

That is, God knows, under various hypothetical antecedents $H$, whether agent $S$ would freely do $A$ or freely refrain from doing $A$. Then, if he decides to create a world containing $H$, he knows that $S$ will do $A .{ }^{117}$ For instance, he knows that, if David stayed in Keilah, Saul would besiege the city, while there is no incompatibility between David staying in Keilah and Saul not besieging it.

The theory's central tenet is that the truth or falsity of any FCC escapes the control of God's will, and in this respect, middle knowledge is akin to natural knowledge: "before any free determination of His will, by virtue of the depth of His natural knowledge... He discerns what the free choice of any creature would do by its own innate freedom" (Concordia, disp. 49, n. 11, trans. Freddoso, 119).118 However, FCCs are contingently true, because their truth depends on what creatures would freely do. ${ }^{119}$ The content of middle knowledge is such that though it escapes God's power it is not essentially so, and in this respect, it shares common features with free knowledge. ${ }^{120}$

Now, according to Scotus, natural and free knowledge are mutually exclusive and jointly exhaustive, since the root of contingency must be traced back to God's will. Thus the whole charge against the divine ideas account rested on the claim that purely conceptual connections escape the will's power and are therefore necessary. ${ }^{121}$ Molina turns the Scotist

117 Freddoso uses the device of Creation situations in his presentation of Molinism. Intuitively, the idea is that God cannot create any possible worlds he pleases, but only those that are part of a Creation situation. As he writes ("Introduction," 49): "if God knows prevolitionally in $C S(w)$ that Adam will sin if placed in $H$, then He cannot arrange things in such a way that Adam will be in $H$ and yet not sin... Over this fact God has no control." Of course, God may decide to create a world with a different condition in which Adam would not sin, but that would constitute another Creation situation.

118 Concordia, disp. 52, n. 10, trans. Freddoso, 168: "such knowledge should in no way be called free, because it is prior to any act of God's will and also because it wat not within God's power to know through this type of knowledge anything other than what He in fact knew"; n. 12: "[God] knows through it middle knowledge, not freely, but quasi-naturally."

119 Concordia, disp. 50, n. 15, Freddoso, 140-41; disp. 52, n. 9; De scientia Dei, ed. Stegmüller, 240.

120 Concordia, disp. 52, n. 10, Freddoso, 169: "therefore it is no more natural for God to know through this sort of knowledge one part of a contradiction than it is for Him to know the opposite part."

121 In addition to the references above, see the following passage: "nullum subiectum continet nisi veritates necessarias de ipso, quia ad contingentes de ipso aequaliter se habet ex se et ad opposita" (Scotus, Ord. Prol. q. un., p. 3, n. 169, Vat. I, 112-13). 
argument on its back. Since the that God's will is the root of contingency destroys human freedom, the only way to save the latter is to claim that knowledge of what free creatures would do in various circumstances is prior to any actual decision on God's part. This, in turn, entails the denial of the Scotist claim that the extent of God's will settles the limits of what is contingent. ${ }^{122}$

There are two further points within the theory of scientia media that need some discussion. First, the theory requires a substantial use of the notion of possible worlds. As we have seen above, although there are elements in Scotus's thought which invite to ascribe him a possible worlds modal framework, nevertheless total states of affairs or combinations of unactualized possibilities into unified worlds do not have a specific role, in part because the notion of compossibility alone does not provide enough resources to define a whole possible world. But the main reason is that every contingently unified ordo rerum is a possible object for God's choice. Thus if it is possible that the past history of the actual world be exactly as it is now, call it $h$, and some state of affairs $s$ contingently obtains now, then the combination $h \&$ not-s is another possible object of God's choice. But then it is indifferent to say either that God actualizes a collection of compossible states of affairs or that he actualizes a complete ordo rerum. Talk of possible worlds is inessential within Scotus's modal framework. But things change once we say that some FCCs are true independently of God's choice. In Molina, expressions like ordo, series rerum, combinatio, or even mundus are not occasionally mentioned, but systematically used in order to describe complete sets of circumstances that are the object of divine choice. The following passage is especially striking:

God in His eternity before the free determination of His will to create or produce something, from the intuition of His essence and power, knew by a natural knowledge everything He could do, that He could create this world,

122 Concordia, disp. 50, n. 15, trans. Freddoso, 140: "and so we disagree with Scotus, because we hold that the explanation for God's knowing with certainty which part of any contradiction among those contingent states of affairs... is going to obtain it not a determination of the divine will..." Molina's charge in disp. 53 against those who try to account for God's knowledge of FCC through his conditional decrees can be applied to the similar move a Scotist could do. The 17th-century Scotist, Bartolomeo Mastri (also known as Princeps scotistarum), advanced such a view of God's knowing FCCs through his actual decree that if it were that $H$, then $S$ would do A. Cf. Disputationes theologicae in I librum Sententiarum (Venice: 1684), d. 3, q. 4, a. 4, n. 256; 193b. For Mastri's overall position on the issues discussed here, see J.-P. Anfray, "Prescience divine, décrets concomitants et liberté humaine d'après Bartholomeo Mastri," in Saggi sul pensiero filosofico di Bartolomeo Mastri (1602-1673), ed. M. Forlivesi (Padova: 2006), 555-92. 
and infinitely many others that he could create this one in this or that part of time or any other, that He could create in it these angels, or infinitely many others... that He could grant to each single man such or such a complexion, or not this one but another; and so on for the infinitely many other orders and combinations of things and circumstances that His omnipotence could do in this universe.

One should know in addition, that [God] in His eternity and before the determination of His will, by the same natural knowledge stemming from the absolute comprehension and penetration of the things and causes, saw what would be future if He chose to produce this or that order, what any angel, left to his own free will, would do by his innate freedom with such and such helps and, given these or those occasions and circumstances, what any man ... would do by his innate freedom, while he could nonetheless do the contrary if he willed so, and under the same set of circumstances, temptations and occasions (De scientia Dei, Stegmüller, 239).

In the first paragraph, Molina describes possible worlds as alternatives to God's choice. But the second paragraph shows that even if, for instance, a world where Peter does not deny Christ is a possible world, it is not an object for God's choice, which is restrained by what Peter would do under such circumstances. The truth of FCCs (of what some call conditionals of freedom) constitutes a barrier beyond which God's power does not extend. By giving such a prominence to the truth of FCCs over possible worlds, Molina might seem to downplay the idea of a possible world. But this is not so. If some state of affairs $s$ depends on what a free creature would do, then God would no longer have a choice between actualizing world $w$ where $h \& s$ obtain and actualizing world $w^{\prime}$ where $h \&$ not-s obtain. Suppose it is true that if it were that $h$, then it would be that $s$, then that God wants $h$ to obtain, he must actualize $s$. And since God acts according to an overall providential plan, if he wants some combination of circumstances to obtain, he must actualize all the FCCs that follow from them. This collection describes a unique set of states of affairs, and makes up a single possible world. This is especially important to account for the realization of God's providential project. Scotus sees it as a sequential process, including many distinct decrees, ordered according to instantia naturae: thus first God wills the principal goal of creation, namely the Incarnation of his son, and then he predestines some to glory, and finally he permits Adam's $\sin ^{123}$ On the contrary, according to Molina, God knows what would happen in each ordo rerum considered as a complete history of the world and single unified creation

123 Scotus, Ordinatio III, d. 7, q. 3, passim, in particular n. 67, Vat. IX, 288-89. 
decree rationally grounded on his scientia media. ${ }^{124}$ The end is therefore not specified independently from the means to attain it, which entails that, had Adam not sinned, God would not have incarnated himself.

Thus with Molina, the notions of asking what would happen in a given world, and thereby of truth in a world, become central. And thus far, the theory of middle knowledge is an important step between the Scotist notion of a possible logicum and the modern notion of a possible world. ${ }^{25}$

Second, Molina's account of middle knowledge can be seen as a revised version of the divine ideas account, as is confirmed by his explanation of the medium of God's middle knowledge:

It is absolutely true that the ideas (or the divine essence known as the primary object) are the firm and certain explanation for the fact that God, who comprehends in the deepest way both Himself and the things that $\mathrm{He}$ contains eminently, knows future contingents (Concordia, disp. 50, n. 16, trans. Freddoso, 142).

Molina grants that ideas are not sufficient to ground God's foreknowledge of actual future contingents, since a divine decree must be added. Nonetheless, ideas as intellectual representations prior to God's decrees are an appropriate characterization of the object of middle knowledge. ${ }^{126}$ Such ideas are not distinct from God's essence, because following orthodoxy, Molina claims that God's knowledge is not taken from things. ${ }^{127} \mathrm{He}$ disagrees with those who ascribe to Scotus the idea that God knows things in their objective being understood as a divine production in an esse deminutum. On the contrary, he rightly ascribes to Scotus the view that God's essence is the primary object of his cognition. ${ }^{128}$ However, he departs

124 Commentaria, q. 23, a. 4-5, disp. 1, memb. 7, 313a: "at ita, propter plenissimam deliberationem, cognitionemve, qua futura omnia, ex hypothesi praevidebat, meditandus est elegisse simul totum ordinem illum."

125 See T. Ramelow, Gott, Freiheit, Weltenwahl, Der Ursprung des Begriffes der besten aller möglichen Welten in der Metaphysik der Willensfreiheit zwischen Antonio Perez (1599-1649) und G.W. Leibniz (1646-1717) (Leiden et al.: 1997) and J. Schmutz, "Qui a inventé les mondes possibles?" Cahiers de Philosophie de l'Université de Caen 42 (2004): 9-45 for detailed analyses of the evolution of the notion of possible world within the debates around scientia media.

126 Concordia, disp. 50, n. 17-20.

127 Commentaria in primam D. Thomae partem, q. 14, a. 5 and 6, disp. un (Lyon: 1622), 154a.: "[intellectus divinus] primo fertur in suam essentiam, ut in obiectum primarium, in quo virtute continentur naturae aliarum rerum, et mediante essentia ita cognita illo eodem intuitu cognoscit ac intuetur ulterius, ut obiectum secundarium, naturam cuiusque aliarum rerum propriam."

128 Commentaria, ibid., 155a. 
from Scotus and aligns with Aquinas, by claiming that ideas as such are not to be identified with the essences or natures of things, but are identical with God's essence. ${ }^{129}$ Molina justifies this by appeal to the further claim that the creatures' essences are not possible through themselves, but owe their possibility to God's power. ${ }^{130}$ And this is clearly in opposition to the standard interpretation of Scotus. Moreover, the identification of ideas with God's essence is closely connected to another specifically Molinist claim, namely that God's knowledge is more perfect than its objects, or more precisely, that, in virtue of God's infinite superiority to the known objects, something can be epistemically determinate within God, in other words, God can be certain about it, even if it is metaphysically indeterminate. This property of God's knowledge is what Molina calls supercomprehensio. ${ }^{131}$ Without entering into the intricacies of this doctrine, what is clear is that it is close in spirit to the Neoplatonic thesis that what is known has the character of the knower, so that a most perfect being can know what is indeterminate in itself. ${ }^{132}$ Such an idea somehow comes to the surface in Thomas Aquinas's treatment of God's foreknowledge, when he claims that a thing's mode of being is not necessarily the same as its esse cognitum. It entails that knowledge with respect to God

129 Commentaria, q. 15, a. 1, disp. 2, 242a: "comparatione intellectus divini essentia divina propriissime habet rationem ideae creaturarum, et non ipsae naturae rerum. Haec est contra Scotum, Durandum, et reliquos..."

130 Commentaria, ibid.: "exemplar igitur primum, in quo a Deo fieri posse conspicitur... non est ipsamet natura humana habens rationem entis, sed essentia divina, in qua virtute continetur, et cuius potest esse participatio, eam suo modo imitando."

131 The fullest account of the doctrine is to be found in Concordia, disp. 52, n. 11-18. Molina says at $\mathrm{n}$. 11 that "in order to see which part a free being will turn itself toward ... what is required is an absolutely profound and absolutely pre-eminent comprehension, such as is found only in God with respect to creatures." The chiasm between an object's intrinsic knowability (its metaphysical determinateness) and the possibility that some infinite being be able to know it is clearly affirmed ibid., n. 17: "[that] things that are knowable in the object by their very nature or because of their being, but it is not true of those things that are known in a way exceeding their nature solely because of the eminence and unlimited perfection of the knower." Cf. Commentaria, q. 16, disp. 1, 246b: "quia Deus non sumit talem cognitionem suam nec certitudinem illius a rebus ipsis contingenter futuris, quae in utramque partem possunt evenire, sed ex altissima comprehensione rerum ominum in sua essentia, ut in primario obiecto, atque ex infinita, omnique ex parte illimitata perfectione sui intellectus eam habet, inde est quo mensura veritatis illius scientiae nulla ratione sit obiectum secundarium, hoc est, essentia divina una cum libera determinatione voluntatis divinae." On this, see Freddoso "Introduction," 50-53; Craig, The Problem of Divine Foreknowledge, 179-83.

132 See in particular Boethius, Consolatio philosophiae, V, pr. 4, l. 75-77,-ه: "omne enim quod cognoscitur non secundum sui vim, sed secundum cognoscentium potius comprehenditur facultatem." Fo eharaeterize this, Hoenen 1993 (172) eontrasts sueh an epistemologieal subjectivism with epistemologieal objectivism. 
and to creatures is at most an analogical concept, and in so far, Molina seems to share Aquinas's conception of the divine attributes. ${ }^{133}$ And in turn, this is clearly at odds with Scotus's metaphysics and rational theology, the starting point of which lies in the univocity of the concept of being, of its attributes, and of other perfections. ${ }^{134}$

What emerges from this study is that it is almost impossible to give a onesided appraisal of Molina's relation to Scotus. Both thinkers a strong notion of metaphysical freedom, but they do not articulate it with exactly the same metaphysical hindsight. The discussions around the relation of time and modality and about the grounds of knowledge have shown that Molina is sometimes closer to ancient modal and cognitive paradigms than it might have seemed at first glance. However, no account of foreknowledge provides a prima facie so complete reconciliation of God's foreknowledge with a libertarian view of free will than the doctrine of middle knowledge. And so, to close this study, we should if it is some light on Scotus's theory through the lens of Molinim. As we saw above, some passages in the Subtle Doctor lend themselves almost naturally to a quasi-Molinist reading. Thus, in Ord. II, d. 34-37, Scotus seems to claim that there is a kind of dependency, more precisely a counterfactual dependency between a creature's free decision and God's decreeing its occurrence, such that, if the creature had willed differently, so would have God. Until now, this dependency has been understood along Ockhamist lines. But there might also be a Molinist interpretation if one adds that God knows what a creature would do before (in our way of conceiving) decreeing anything. And so, as Molina himself remarks in at least one place, Scotus's theory, if considered as incomplete, is not incompatible with the Molinist account:

If therefore, Scotus, when he says that God foreknows future contingents in the determination of His free will, conceives according to the sense that

133 See $S T$ I, q. 14, a. 6, ad. 1; a. 13, ad. 2. On the analogy of divine attributes, see $S T$ I, q. 13. See L.J. Elders, The Philosophical Theology of S. Thomas Aquinas (Leiden et al.: 1990).

134 Scotus, Ord. I, d. 3, p. 1, q. 1-2, n. 26-55, Vat. III, 18-38. On the univocity of the concept of being, see the studies in Part IV of Honnefelder et al., John Duns Scotus: Metaphysics and Ethics. In the particular case of divine perfections like intelligence or will, Scotus claims that infinity does not destroy the formal nature of that to which it is added (Ord. I, d. 8, q. 4, n. 17). 
has been explained, and that, assuming this natural knowledge by which $\mathrm{He}$ eternally knew all future contingents in their future being, not absolutely but conditionally such; and if by the free determination of His will [God] decided to create this or that order of things with these or those circumstances, then what he says is true and agrees with ourselves (De scientia Dei, Stegmüller, 240).

Molina acknowledges that Scotus could be read as claiming that divine decrees provide a sufficient ground for God's knowing what will (unconditionally) exist, but that such a free knowledge is preceded by God's knowledge of FCC. This reading was not uncommon turing the $17^{\text {th }}$ century among Scotists. ${ }^{135}$ And among recent scholars, those who hold a libertarian interpretation of his teaching on free will are led to ascribe a similar position to Scotus. In other words, in order to fill the gap between God's knowledge as based on his decrees and the counterfactual dependence of his decrees upon what a free creature would do under such and such circumstances, one would have to add something like middle knowledge to Scotus's account. ${ }^{136}$ In this respect, Molina's innovations can help to shed new light on the Subtle Doctor's thought.

135 Especially important "Molinist Scotists" are John Punch and Filippo Fabri. Cf. Filipppo Fabri, Disputationes theologicae (Venice: 1619), I, dist. 39, dispe 53, n. 22-23, 325 b: “... contingentia provenire et a voluntate divina, et simul etiam a voluntate creata, quae est causa proxima..."; op. cit., disp. 54, n. 42, 337a: "Molina et alii sentiunt ergo in re cum Scoto"; ibid., n. 50, 338b: "ad salvandum libertatem nostrae voluntatis, et contingentiam in rebus sufficit quod decretum illud divinae voluntatis sequatur praevisionem, quid sit volitura mea voluntas."

136 This is approximately the conclusion reached by Dekker. See "Does Scotus Need Molina?" 109-10. In the end, however, he thinks that the theory of middle knowledge as a name for the process of God's cognition does not lead further than Scotus's own account in terms of decrees. The theory of middle knowledge only gives a finer explanation of the way of reconciling God's foreknowledge and created free will. 